FY 2006

\title{
BARRIERS TO THE APPLICATION OF HIGH-TEMPERATURE COOLANTS IN HYBRID ELECTRIC VEHICLES
}

Prepared by:

Oak Ridge National Laboratory

Mitch Olszewski, Program Manager

\section{Submitted to:}

Energy Efficiency and Renewable Energy

FreedomCAR and Vehicle Technologies

Vehicle Systems Team

Susan A. Rogers, Technology Development Manager

September 2006 
NATIONAL LABORATORY

MANAGED BY UT-BATTELLE

FOR THE DEPARTMENT OF ENERGY
Engineering Science and Technology Division

\section{BARRIERS TO THE APPLICATION OF HIGH-TEMPERATURE COOLANTS IN HYBRID ELECTRIC VEHICLES}

J. S. Hsu

R. H. Staunton

M. R. Starke

Publication Date: September 2006

Prepared by the

OAK RIDGE NATIONAL LABORATORY

Oak Ridge, Tennessee 37831 managed by

UT-BATTELLE, LLC

for the

U.S. DEPARTMENT OF ENERGY

Under contract DE-AC05-00OR22725 


\section{DOCUMENT AVAILABILITY}

Reports produced after January 1, 1996, are generally available free via the U.S. Department of Energy (DOE) Information Bridge:

Web site: http://www.osti.gov/bridge

Reports produced before January 1, 1996, may be purchased by members of the public from the following source:

National Technical Information Service

5285 Port Royal Road

Springfield, VA 22161

Telephone: 703-605-6000 (1-800-553-6847)

TDD: $703-487-4639$

Fax: 703-605-6900

E-mail: info@ ntis.fedworld.gov

Web site: http://www.ntis.gov/support/ordernowabout.htm

Reports are available to DOE employees, DOE contractors, Energy Technology Data Exchange (ETDE) representatives, and International Nuclear Information System (INIS) representatives from the following source:

Office of Scientific and Technical Information

P.O. Box 62

Oak Ridge, TN 37831

Telephone: 865-576-8401

Fax: 865-576-5728

E-mail: reports@osti.gov

Web site: http://www.osti.gov/contact.html

This report was prepared as an account of work sponsored by an agency of the United States Government. Neither the United States government nor any agency thereof, nor any of their employees, makes any warranty, express or implied, or assumes any legal liability or responsibility for the accuracy, completeness, or usefulness of any information, apparatus, product, or process disclosed, or represents that its use would not infringe privately owned rights. Reference herein to any specific commercial product, process, or service by trade name, trademark, manufacturer, or otherwise, does not necessarily constitute or imply its endorsement, recommendation, or favoring by the United States Government or any agency thereof. The views and opinions of authors expressed herein do not necessarily state or reflect those of the United States Government or any agency thereof. 


\section{TABLE CONTENTS}

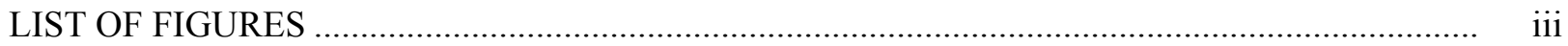

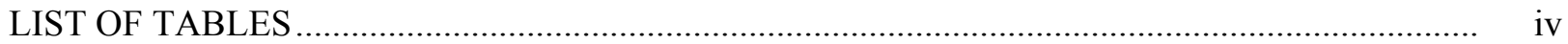

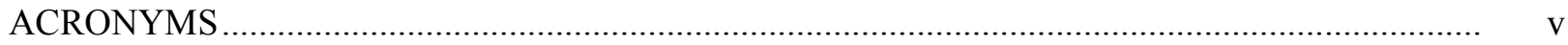

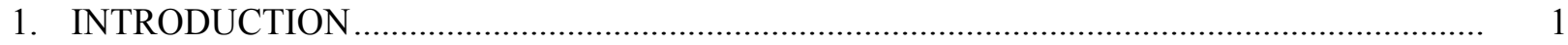

2. CONFIGURATIONS OF LOW- AND HIGH-TEMPERATURE COOLANT DESIGNS........... 2

2.1 PRIUS LOW-TEMPERATURE COOLANT-LOOP ARCHITECTURE ........................... 2

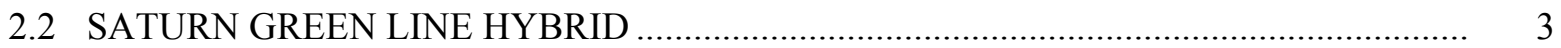

2.3 CONFIGURATIONS VS. POWER LEVELS .............................................................. 5

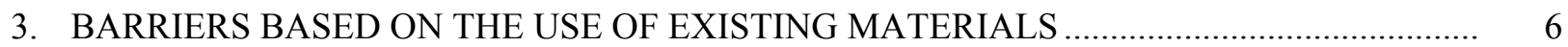

3.1 INVERTER/CONVERTER POWER ELECTRONICS CIRCUITRY ............................... 6

3.1.1 Assessment of High-Temperature Power Electronic Devices .................................... 6

3.1.2 Cycle Lifetime of Power Modules and Wire Bonding ............................................ 8

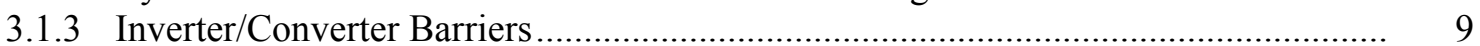

3.2 THERMAL ASSESSMENT OF HIGH-TEMPERATURE DC-LINK CAPACITORS ....... 10

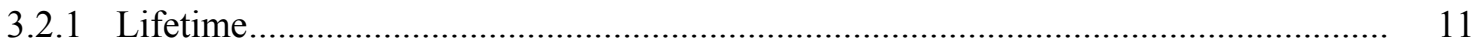

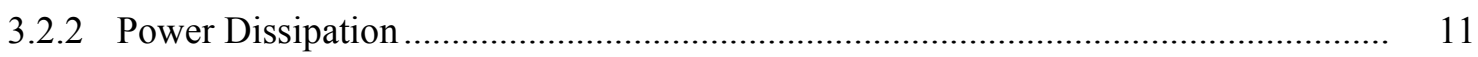

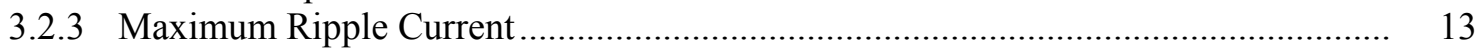

3.2.4 Availability of Capacitors and Related Barriers .................................................. 15

3.3 THERMAL ASSESSMENT OF A PMSM.......................................................... 16

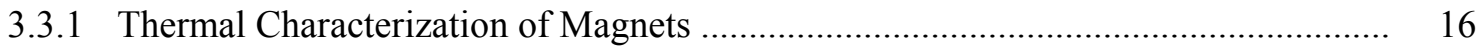

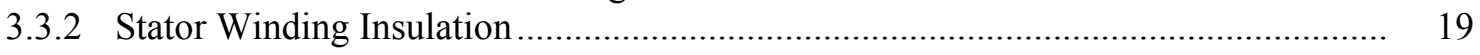

3.3.3 PMSM Test Data and Physical Assessment ...................................................... 20

3.3.3.1 Temperature margin for PMs based on parametric model ....................... 20

3.3.3.2 Continuous power derating in a PMSM at two coolant temperatures......... 21

3.3.3.3 Design approach for the PMSM ............................................................. 21

3.3.4 PMSM Barriers Resulting from Higher Coolant Temperature ................................. 24

3.4 SYSTEM-LEVEL ASSESSMENT ........................................................................... 25

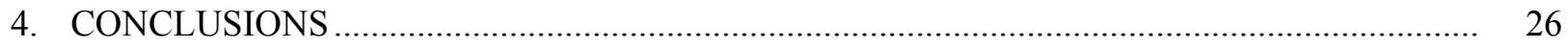

APPENDIX A - CALCULATIONS OF INVERTER LOSSES VS. TEMPERATURE .................... 29

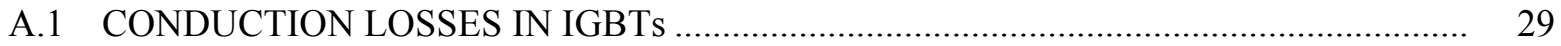

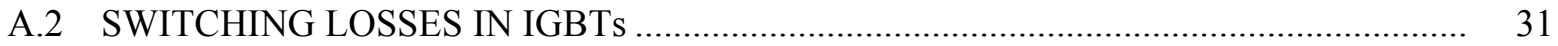

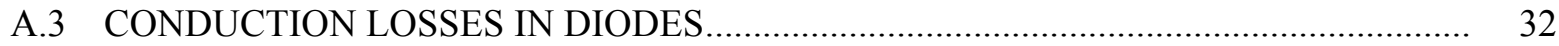

A.4 POWER DISSIPATION OF POWER ELECTRONIC DEVICES …............................... 33

APPENDIX B - ANALYTICAL ASSESSMENT OF A PMSM CIRCUIT ..................................... 36

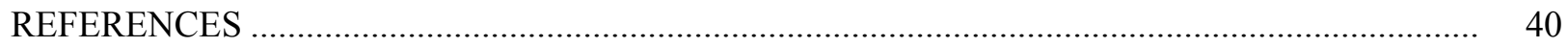




\section{LIST OF FIGURES}

Figure $\quad$ Page

2.1 Toyota Prius diagram of the engine and hybrid system cooling loops ............................. 2

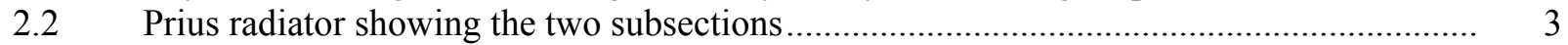

2.32004 Prius inverter/converter cold plate and mounted module locations........................... 3

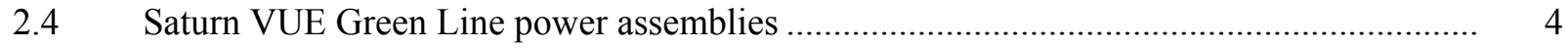

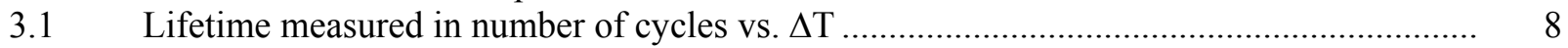

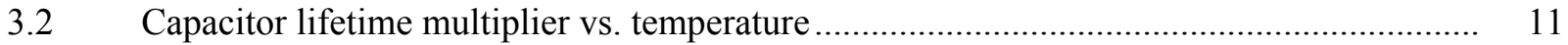

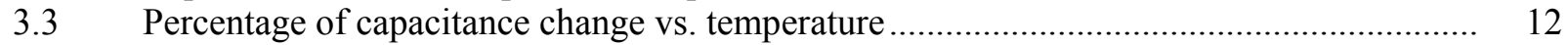

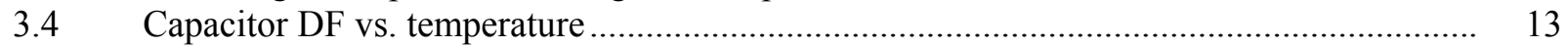

3.5 Capacitor power dissipation vs. temperature .............................................................. 13

3.6 Modular capacitor position and size in the Prius inverter/converter casing ...................... 14

3.7 Ripple current vs. ambient temperature for high-temperature capacitors........................... 15

3.8 Flux strength of a selected NdFeB magnet vs. temperature ............................................ 18

3.9 Average motor insulation life vs. winding temperature for four insulation types ............... 19

3.10 Predicted temperature profiles for the Prius rotor and magnets $\left(50^{\circ} \mathrm{C}\right.$ cooling)................ 21

3.11 Prius cooling loop and heat flow for the hybrid subsystems ....................................... 22

3.12 Thermal time-profile of Prius motor during current increase and decrease ...................... 23

3.13 General PMSM design approach applicable for high-temperature cooling....................... 24

A.1 IGBT dissipated power vs. temperature in respect to current........................................... 29

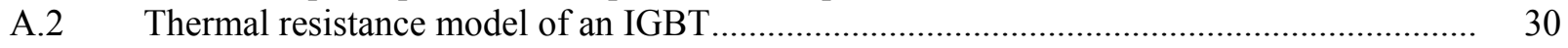

A.3 IGBT switching energy vs. temperature at maximum rated current (50A) ...................... 31

A.4 IGBT switching power vs. temperature in respect to frequency ...................................... 32

A.5 Standard inverter diagram with six switches and six diodes ........................................... 33

B.1 Example of PMSM back-emf vs. PMSM temperature .................................................. 36

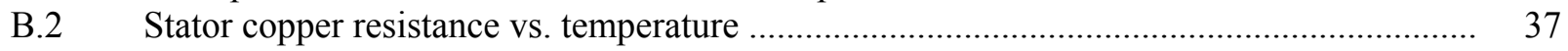

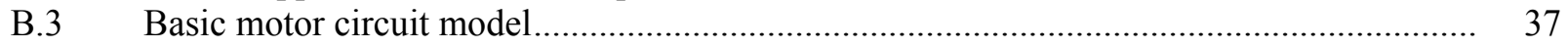

B.4 PMSM circuit model predicted efficiency vs. temperature ............................................ 39 


\section{LIST OF TABLES}

Table

$2.1 \quad$ Summary of selected HEV technologies ........................................................................ 5

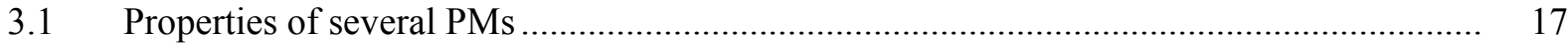

3.2 Characteristic of Delco Remy MQ2 NdFeB magnets .................................................... 18

3.3 Estimate of life-shortening hours accrued during 15 years of city driving .......................... 20

3.4 Itemized listing of costs of eliminated components..................................................... 25

4.1 Estimations of additional cost to resolve barriers in components/subsystems .................... 27

4.2 Multi-parameter, temperature-based qualitative comparison .......................................... 28

A.1 Temperature-dependent conduction losses in an IGBT ................................................. 30

A.2 Conduction losses in an IDW75E60 power diode ..........................................................

A.3 Full bridge inverter diode losses using the conduction loss equation................................. 34

A.4 IGBT conduction and switching losses in a full bridge inverter ...................................... 34

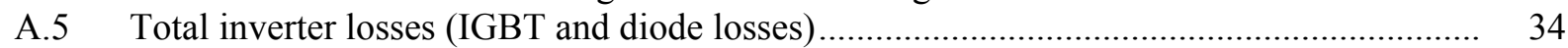

A.6 Switching and total inverter efficiency ................................................................. 35

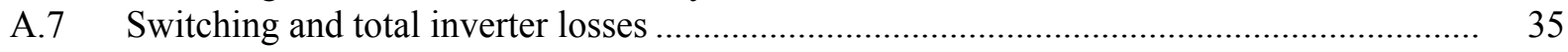

B.1 Example motor for back-emf analysis ................................................................... 36 


\section{ACRONYMS}

$\begin{array}{lrlr}\text { DF } & \text { dissipation factor } & \text { OEM } & \text { original equipment manufacturer } \\ \text { DOE } & \text { U.S. Department of Energy } & \text { ORNL } & \text { Oak Ridge National Laboratory } \\ \text { emf } & \text { electromotive force } & \text { PM } & \text { permanent magnet } \\ \text { FCVT } & \text { FreedomCAR and Vehicle Technologies } & \text { PMSM } & \text { permanent magnet synchronous motor } \\ \text { HEV } & \text { hybrid electric vehicle } & \text { PWM } & \text { pulse-width modulation } \\ \text { HV } & \text { high voltage } & \text { RMS } & \text { root-mean square } \\ \text { IGBT } & \text { insulated-gate bipolar transistor } & \mathrm{Si} & \text { silicon } \\ \text { ISR } & \text { inverter spike resistant } & \mathrm{SiC} & \text { silicon carbon } \\ \text { MOS } & \text { metal-oxide semiconductor } & \mathrm{SmCo} & \text { Samarium Cobalt } \\ \text { NdFeB } & \text { neodymium iron boron } & \mathrm{UQM} & \text { Unique Mobility }\end{array}$




\section{INTRODUCTION}

This study was performed by the Oak Ridge National Laboratory (ORNL) to identify practical approaches, technical barriers, and cost impacts to achieving high-temperature coolant operation for certain traction drive subassemblies and components of hybrid electric vehicles (HEV). HEVs are unique in their need for the cooling of certain dedicated-traction drive subassemblies/components that include the electric motor(s), generators(s), inverter, dc converter (where applicable), and dc-link capacitors. The new coolant system under study would abandon the dedicated $65^{\circ} \mathrm{C}$ coolant loop, such as used in the Prius, and instead rely on the $105^{\circ} \mathrm{C}$ engine cooling loop.

This assessment is important because automotive manufacturers are interested in utilizing the existing water/glycol engine cooling loop to cool the HEV subassemblies in order to eliminate an additional coolant loop with its associated reliability, space, and cost requirements. In addition, the cooling of power electronic devices, traction motors, and generators is critical in meeting the U.S. Department of Energy (DOE) FreedomCAR and Vehicle Technology (FCVT) goals for power rating, volume, weight, efficiency, reliability, and cost. All of these have been addressed in this study.

Because there is high interest by the original equipment manufacturers (OEMs) in reducing manufacturing cost to enhance their competitive standing, the approach taken in this analysis was designed to be a positive "can-do" approach that would be most successful in demonstrating the potential or opportunity of relying entirely on a high-temperature coolant system. Nevertheless, it proved to be clearly evident that a few formidable technical and cost barriers exist and no effective approach for mitigating the barriers was evident in the near term.

Based on comprehensive thermal tests of the Prius reported by ORNL in 2005 [1], the continuous ratings at base speed $(1200 \mathrm{rpm})$ with different coolant temperatures were projected from test data at $900 \mathrm{rpm}$. They are approximately $15 \mathrm{~kW}$ with $103^{\circ} \mathrm{C}$ coolant and $20 \mathrm{~kW}$ with $50^{\circ} \mathrm{C}$ coolant. To avoid this $25 \%$ drop $^{1}$ in continuous power, design changes for improved heat dissipation and carefully managed changes in allowable thermal limits would be required in the hybrid subsystems. This study is designed to identify the technical barriers that potentially exist in moving to a high-temperature cooling loop prior to addressing the actual detailed design.

For operation at a significantly higher coolant temperature, there were component-level issues that had to be addressed in this study. These issues generally pertained to the cost and reliability of existing or nearterm components that would be suitable for use with the $105^{\circ} \mathrm{C}$ coolant. The assessed components include power electronic devices/modules such as diodes and insulated-gate bipolar transistors (IGBTs), inverter-grade high-temperature capacitors, permanent magnets (PM), and motor-grade wire insulation. The need for potentially modifying/resizing subassemblies such as inverters, motors, and heat exchangers was also addressed in the study.

In order to obtain pertinent information to assist ORNL researchers address the thermal issues at the component, module, subassembly, and system levels, pre-existing laboratory test data conducted at varying temperatures was analyzed in conjunction with information obtained from technical literature searches and industry sources.

\footnotetext{
${ }^{1}$ This would be reduced to a $20 \%$ drop for the subject temperatures $\left(65^{\circ} \mathrm{C}\right.$ and $\left.105^{\circ} \mathrm{C}\right)$.
} 


\section{CONFIGURATIONS OF LOW-AND HIGH-TEMPERATURE COOLANT DESIGNS}

This section begins with a description of the Prius coolant systems and then considers an alternative hightemperature HEV coolant system that is presently used in the automotive market. Much of the material in this section is based on ORNL's benchmarking study of the 2004 Prius [2].

\subsection{PRIUS LOW-TEMPERATURE COOLANT-LOOP ARCHITECTURE}

The subsystems of the main traction drive that require cooling in the Prius consist of the inverter, engine, motor, and generator. Figure 2.1 shows the two water/glycol loops that cool the hybrid components and the gasoline engine. The hybrid cooling loop, as depicted, is complete; however, the engine cooling loop does not show (1) the passenger compartment heater core and dashboard water valve (both being very conventional) and (2) the insulated coolant heat storage tank and associated water pump. This latter system supplies hot coolant to the engine to preheat the intake port of the engine. This improves fuel injection, reduces adhesion of fuel onto the intake port wall, and reduces hydrocarbon exhaust emissions. For the purposes of this study, the basic engine cooling system, as depicted, will be considered for the hybrid cooling system.

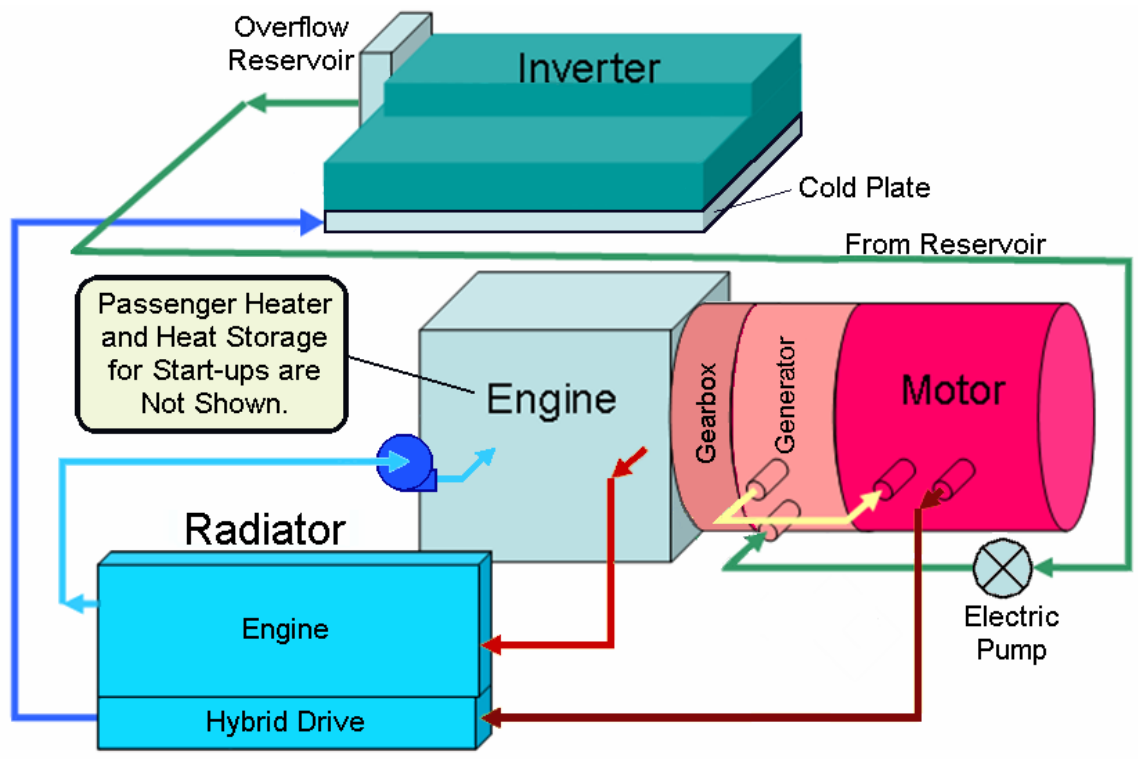

Fig. 2.1. Toyota Prius diagram of the engine and hybrid system cooling loops.

The low-temperature hybrid cooling loop uses a 12-Vdc electric pump to transfer $65^{\circ} \mathrm{C}$ coolant from the radiator first to the inverter, then to the generator, and lastly to the motor thus cooling all the main traction drive subsystems sequentially. The second loop sends $105^{\circ} \mathrm{C}$ coolant from the radiator to the engine using a conventional coolant pump. To provide these two different temperature loops, the radiator is divided into two sections as seen in Fig. 2.2. 


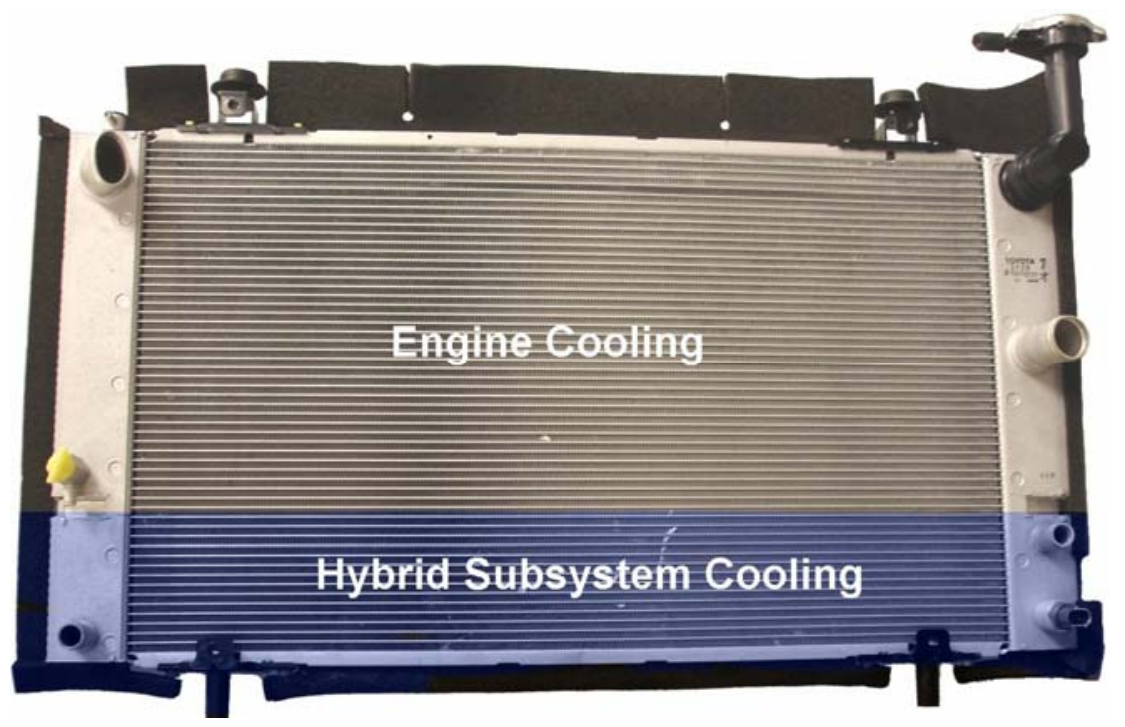

Fig. 2.2. Prius radiator showing the two subsections.

Figure 2.3(a) shows the inside compartment of the 2004 Prius inverter/converter casing in which the lid and all internal components were removed. Clearly shown is the integral cold plate that is covered with white thermal grease. Figure 2.3(b) shows three assemblies bolted to the top of the cold plate with thermal grease: (1) the inverter driver board/power electronics module, (2) buck/boost converter power module, and (3) converter transformer. The dc-link capacitor module is located high in the casing and the cooling loop does not provide cooling directly to the module as it does for the bolted down assemblies. Instead, the capacitor is passively cooled within the aluminum casing. If the engine compartment were to become very hot, the $65^{\circ} \mathrm{C}$ cold plate would help to limit the temperatures inside the inverter/converter casing. Clearly, if the temperature of the cold plate were increased to $105^{\circ} \mathrm{C}$, the inverter driver board, power electronics, and all other components in the casing would have to operate at elevated temperatures.

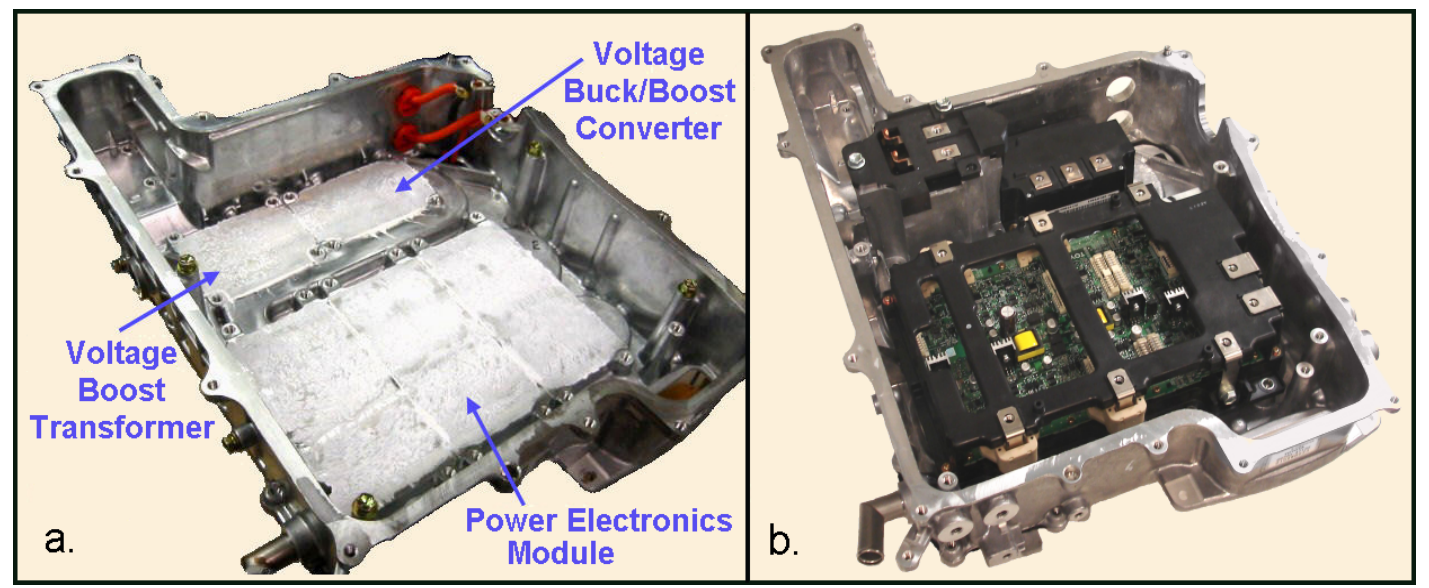

Fig. 2.3. 2004 Prius inverter/converter cold plate and mounted module locations.

\subsection{SATURN GREEN LINE HYBRID}

The VUE Saturn Green Line, with sales beginning in 2006, is a significant product relative to this study in that the inverter subsystems were designed to be cooled without the inclusion of a low-temperature 
dedicated cooling loop. Figure 2.4 shows the VUE Green Line engine/motor assembly, a close-up of the motor-generator unit, and the power electronics assembly that includes the motor inverter.

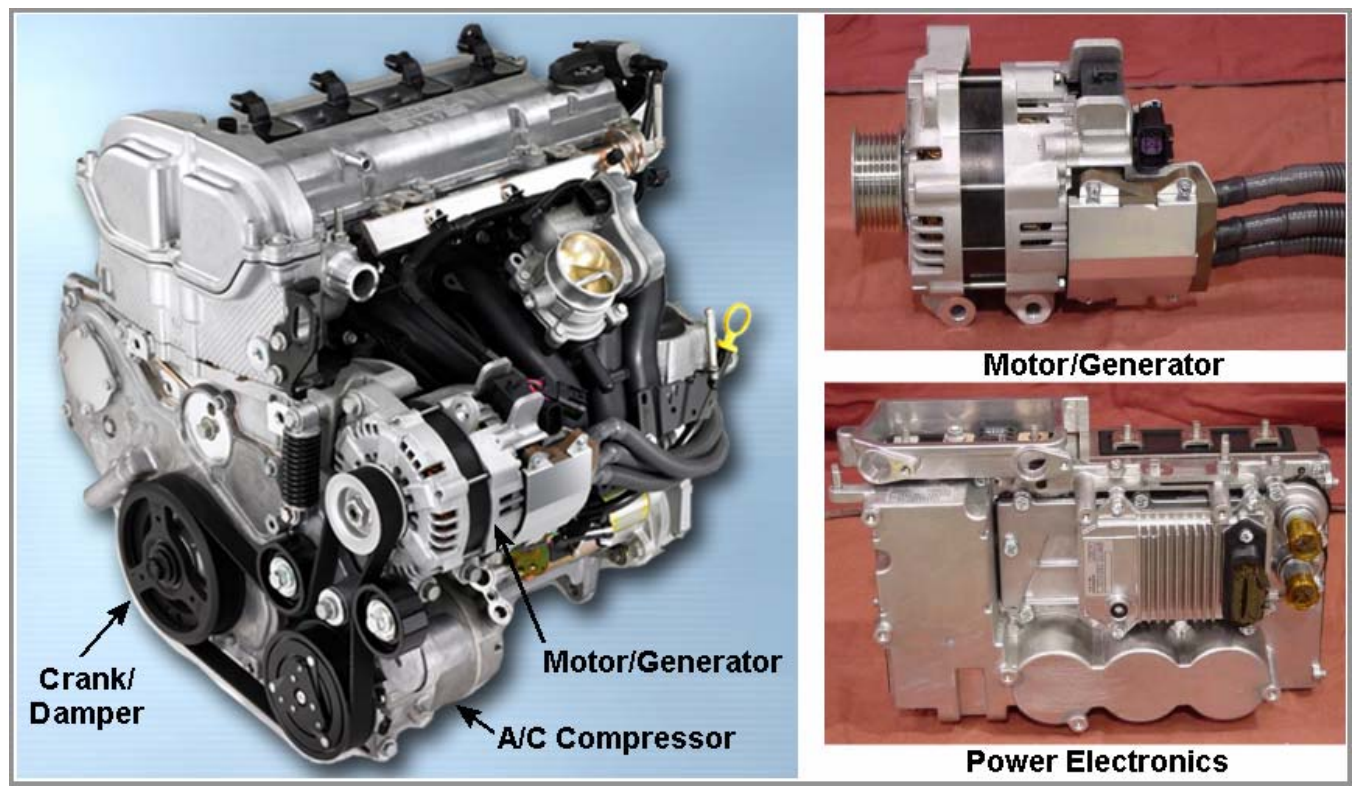

Fig. 2.4. Saturn VUE Green Line power assemblies.

The following are design features selected by the Saturn Motor Company and included in the VUE Saturn Green Line [3]:

1. The Saturn Green Line motor photos clearly show that the motor uses an air-cooled, open-frame design. The motor uses a dual-fan technique that concentrates most of the air flow to the ends of the motor. The air flow path begins at the center vent holes (the intake) and the air flows out at the outer vent holes of each end. The motor does not have any liquid coolant loop.

2. The inverter is cooled by the engine coolant-loop radiator discharge line before it provides cooling to the engine.

3. The motor volume is $151 \mathrm{~mm}$ diameter and $150 \mathrm{~mm}$ length from first groove of pulley including the connector (134 mm not including connector).

4. The maximum speed of the motor is $16,000 \mathrm{rpm}$ continuous and $18,500 \mathrm{rpm}$ for $3 \mathrm{~s}$ maximum.

5. The mass of the inverter assembly (which includes the inverter driver electronics, power electronics, cooling plate, $1.5 \mathrm{~kW} \mathrm{DC/DC} \mathrm{converter,} \mathrm{auxiliary} \mathrm{transmission} \mathrm{pump} \mathrm{driver,} \mathrm{and} \mathrm{casing)} \mathrm{is} 6.9 \mathrm{~kg}$ without coolant. Without the auxiliary pump driver, the mass is $6.2 \mathrm{~kg}$.

6. The total packaging envelop of the inverter assembly (inverter driver electronics, power electronics, cooling plate, $1.5 \mathrm{~kW}$ DC/DC converter, auxiliary transmission pump driver, and casing) is specified in the requirements as $300 \mathrm{~mm}$ by $100 \mathrm{~mm}$ by $200 \mathrm{~mm}$ (length, height, and depth, respectively) for a volume of $6 \mathrm{~L}$. 
7. The motor/generator unit is rated at $4 \mathrm{~kW}$ peak mechanical motoring, $5 \mathrm{~kW}$ electrical peak generating, and $3 \mathrm{~kW}$ electrical continuous generating. The unit has a mass of $10.7 \mathrm{~kg}$ including the three-phase cables. The three-phase cable assembly mass is $1.7 \mathrm{~kg}$.

Further information pertaining to the high-temperature inverter was not sought due to the fact that (1) the inverter has a low peak power rating and (2) many of the design details are sensitive and protected.

\subsection{CONFIGURATIONS VS. POWER LEVELS}

No single HEV PM synchronous motor (PMSM) has a peak torque rating as high as in the Prius. Table 2.1 summarizes many competitive HEV systems from Toyota and Honda and includes the Saturn VUE Green Line for comparison. Because the Prius electric traction drive system is well respected in the industry and its peak power rating is near the target of interest $(55 \mathrm{~kW})$, this study will consider the cooling system changes relative to the Prius PMSM and inverter designs. The Prius will be the base case. Some consideration will also be given to Honda innovations although they pertain to lower power systems.

Table 2.1 Summary of selected HEV technologies (2006)

\begin{tabular}{|c|c|c|c|c|c|}
\hline Mfr./Model & $\begin{array}{l}\text { Peak Torque and Power of } \\
\text { Primary Traction Motor }\end{array}$ & $\begin{array}{c}\text { Cooling } \\
\text { Motor }\end{array}$ & $\begin{array}{l}\text { Cooling, } \\
\text { Inverter }\end{array}$ & Top Speed & $\begin{array}{l}\text { Battery/Boost } \\
\text { Specifications }\end{array}$ \\
\hline Honda Insight & $\begin{array}{l}14 \text { hp @ } 3000 \text { rpm (5-spd) } \\
13 \text { hp } @ 3000 \text { rpm (CVT) }\end{array}$ & Passive & $\begin{array}{l}\text { Forced } \\
\text { convective }\end{array}$ & $6000 \mathrm{rpm}$ & $\begin{array}{l}144 \mathrm{~V}(6 \mathrm{Ah}) \\
\text { Ni-MH (boosted } \\
\text { to } 500 \mathrm{~V})\end{array}$ \\
\hline $\begin{array}{l}2004 \text { and later } \\
\text { Toyota Prius }\end{array}$ & $400 \mathrm{Nm}(0-1200 \mathrm{rpm})$ & $\begin{array}{l}\text { Water \& } \\
\text { glycol } \\
\text { using a } \\
\text { low- } \\
\text { temperature } \\
\text { coolant }\end{array}$ & $\begin{array}{l}\text { Water \& } \\
\text { glycol at } \\
65^{\circ} \mathrm{C} \text { (output } \\
\text { to motor) }\end{array}$ & $6000 \mathrm{rpm}$ & $\begin{array}{l}201.6 \mathrm{~V}, 20 \mathrm{~kW}, \\
6.5 \mathrm{Ah} \\
\mathrm{Ni}-\mathrm{MH} \\
\text { (boosted to } 200- \\
500 \mathrm{~V} \text { ) }\end{array}$ \\
\hline $\begin{array}{l}2005 \text { Honda } \\
\text { Civic }\end{array}$ & $\begin{array}{l}62 \mathrm{Nm} @ 1000 \text { rpm in MT } \\
\text { model. }\end{array}$ & Passive & $\begin{array}{l}\text { Forced } \\
\text { convective }\end{array}$ & $6000 \mathrm{rpm}$ & $\begin{array}{l}144 \mathrm{~V} \\
\mathrm{Ni}-\mathrm{MH}\end{array}$ \\
\hline $\begin{array}{l}2006 \text { Honda } \\
\text { Civic }^{1}\end{array}$ & $\begin{array}{l}103 \mathrm{Nm} @ 0 \text { - 1,160 rpm } \\
15 \mathrm{~kW}(20 \mathrm{hp}) @ 2000 \mathrm{rpm}\end{array}$ & Passive & $\begin{array}{l}\text { Forced } \\
\text { convective }\end{array}$ & $6000 \mathrm{rpm}$ & $\begin{array}{l}158 \mathrm{~V} \\
\mathrm{Ni}-\mathrm{MH}\end{array}$ \\
\hline $\begin{array}{l}\text { Honda } \\
\text { Accord }\end{array}$ & $\begin{array}{l}136 \text { Nm@840 rpm } \\
12 \mathrm{~kW}(14 \mathrm{~kW} \text { gen mode })\end{array}$ & Passive & $\begin{array}{l}\text { Forced } \\
\text { convective }\end{array}$ & $6000 \mathrm{rpm}$ & $\begin{array}{l}144 \mathrm{~V}, 13.8 \mathrm{~kW} \\
\text { (6 Ah) } \\
\text { Ni-MH }\end{array}$ \\
\hline $\begin{array}{l}\text { Toyota } \\
\text { Highlander }\end{array}$ & $\begin{array}{l}335 \mathrm{Nm} \text { or } 247 \mathrm{lb}-\mathrm{ft} \\
123 \mathrm{~kW} \text { or } 167 \mathrm{hp} \\
\text { (Rear motor }[4 \mathrm{WD}] \text { : } \\
130 \mathrm{Nm} \text { or } 96 \mathrm{lb}-\mathrm{ft} \\
50 \mathrm{~kW} \text { or } 68 \mathrm{hp} \text { ) }\end{array}$ & $\begin{array}{l}\text { Same as } \\
\text { Prius }\end{array}$ & $\begin{array}{l}\text { Same as } \\
\text { Prius }\end{array}$ & $12,500 \mathrm{rpm}$ & $\begin{array}{l}288 \mathrm{~V} \\
\mathrm{Ni}-\mathrm{MH} \\
\text { (boosted to } \\
650 \mathrm{~V} \text { ) }\end{array}$ \\
\hline $\begin{array}{l}\text { Toyota } \\
\text { Camry }\end{array}$ & $\begin{array}{l}270 \text { Nm@1-1500 rpm } \\
105 \text { kW@4500 rpm }\end{array}$ & $\begin{array}{l}\text { Same as } \\
\text { Prius }\end{array}$ & $\begin{array}{l}\text { Same as } \\
\text { Prius }\end{array}$ & $14,500 \mathrm{rpm}$ & \\
\hline $\begin{array}{l}\text { Saturn VUE } \\
\text { Green Line }\end{array}$ & $\begin{array}{l}4 \mathrm{~kW}(3 \mathrm{~kW} \text { continuous and } \\
5 \mathrm{~kW} \text { in gen mode) }\end{array}$ & $\begin{array}{l}\text { Forced } \\
\text { convection }\end{array}$ & $\begin{array}{l}\text { Engine } \\
\text { coolant }\end{array}$ & $16,000 \mathrm{rpm}$ & \\
\hline
\end{tabular}

${ }^{1} 2006$ Civic motor uses high density windings and stronger magnets to get $20 \%$ power increase in same volume. 


\section{BARRIERS BASED ON THE USE OF EXISTING MATERIALS}

This section considers the potential temperature-related impacts on the performance of materials, components, and subsystems used in a Prius-like HEV traction system. Based on this assessment, this section provides listings of the design barriers that would arise from increasing the cooling loop temperature from $65-105^{\circ} \mathrm{C}$.

This section focuses on (1) the inverter power electronic devices, (2) inverter dc-link capacitors, and (3) selected PMSM components that have the highest vulnerability to operation at elevated temperatures. The barriers that will be identified in each of these three main subsections will be those barriers that may prevent the components and subsystems from operating reliably over a 15 -year service life when cooled by a $105^{\circ} \mathrm{C}$ cooling loop.

Note: The need for increasing radiator size is not assessed in detail in this section because (1) the HEV heat load is small compared to that of the engine and (2) the air-to-coolant differential temperature would be much higher, improving heat dissipation. Therefore, the need for a size change is considered minor or nonexistent.

\subsection{INVERTER/CONVERTER POWER ELECTRONICS CIRCUITRY}

This section considers what barriers may exist to operating the inverter and converter packages at $105^{\circ} \mathrm{C}$. The analysis will consider inverter bus voltages up to $500 \mathrm{Vdc}$ for meeting peak power operation. Similarly, the Prius uses a 500-V boost converter, and the short-duration peak current in each leg of the inverter is $\sim 200 \mathrm{~A}_{\mathrm{rms}}$.

\subsubsection{Assessment of High-Temperature Power Electronic Devices}

Conventional silicon-based ( $\mathrm{Si}$ ) materials and power device packaging designs are clearly insurmountable barriers to the use of a high-temperature coolant since junction temperatures will increase in hightemperature-coolant-based inverters to $\sim 150^{\circ} \mathrm{C}$. For this reason, currently marketed but not fully lifetested devices will be considered in this analysis: Si-based trench IGBTs and high-temperature diodes, both with junction temperature ratings up to $175^{\circ} \mathrm{C}$. These IGBTs and diodes are presently available from several manufacturers.

Although device specifications list " $175^{\circ} \mathrm{C}$ " maximum junction temperatures, the technology for these trench IGBTs and diodes is not mature and, consequently, many design details must be considered that would normally have less importance.

Areas requiring detailed consideration during the design process include:

1. Module Packaging Development - Since the inverter is likely to require 12 IGBTs and 12 diodes (two parallel IGBTs/diodes in each inverter leg) and the buck/boost converter 2 of each, the use of parallel-device modules is virtually a certainty for attaining the needed current levels. For a non-mature technology such as this, each specific parallel-device module design will have its own development process and operating specifications.

2. Current-Dependent Device Ratings - Thermal deratings presently exist for trench IGBTs based on maximum switching current.

3. Temperature Ratings for Switching and Conductance - The temperature ratings for IGBT switching are lower than for conductance. 
4. Must Consider Exactly How the Module is Cooled - For new power electronic devices such as these, the cooling design is not an independent consideration from the device selection, reliability, and overall life. Lifetime testing should be performed using the actual cooling configuration/parameters of the design application.

Recent literature [4] indicates that new 600V IGBTs, using a trench metal-oxide semiconductor (MOS)top-cell with an ultra-thin, 70- $\mu \mathrm{m}$ wafer technology, may be qualified for $175^{\circ} \mathrm{C}$ junction temperature, but the maximum operating temperature under switching conditions is $150^{\circ} \mathrm{C}$. Because high-temperature inverter development has shown that $150^{\circ} \mathrm{C}$ is much better than $125^{\circ} \mathrm{C}$ (see below), this thermal derating is considered to be a minor barrier.

The electronics industry is active in improving the high-temperature performance of IGBTs and diodes and the switching-current limitation may soon be mitigated. The text box (below) describes the hypothetical assessment of the IGBT/diode modules if the IGBTs were able to provide full switching current at a junction temperature of $175^{\circ} \mathrm{C}$. Proceeding on the same forward-looking basis, Appendix A provides an analysis of IGBT and diode losses at varying temperatures and current levels.

\section{Hypothetical Assessment of an Inverter Using $175^{\circ} \mathrm{C}$, Full-Current Power Electronics}

The use of $175^{\circ} \mathrm{C}$ power electronic modules is very advantageous because the device junction temperature rating increase of $50^{\circ} \mathrm{C}$ exceeds the proposed coolant temperature increase of $40^{\circ} \mathrm{C}$. Barring a significant increase in losses at the elevated temperatures (see Appendix A), it appears that replacing the low temperature power electronic module with a high temperature module would significantly aid the redesign process to enable inverter and converter operation using a $105^{\circ} \mathrm{C}$ coolant.

Based on the technical concerns discussed in this section, lifetime testing will be necessary to verify that the high-temperature power electronic devices will have a 15 -year life when used with the $105^{\circ} \mathrm{C}$ coolant system.

The cost impact of replacing $125^{\circ} \mathrm{C}$ junction temperature devices with $175^{\circ} \mathrm{C}$ devices is not expected to be an issue. Trench IGBTs and high-temperature diodes are treated in the industry as part of a normal progression of improved-performance devices and the cost is therefore essentially the same.

On a positive note, Semikron's recent efforts at developing a $133 \mathrm{~kW}$ high-temperature inverter system show the high potential of using presently available power electronic devices. Their analysis showed [5] that the $40^{\circ} \mathrm{C}$ coolant rise did not require an increase in inverter size (considering only power electronics) or in the number of power electronic devices. This was based on (1) using new high-temperature devices, (2) using devices with lower losses, (3) increasing the power density, and (4) improving the heat sink. Only a modest cost increase was projected for the power electronics.

In addition to the power electronics, the $40^{\circ} \mathrm{C}$ increase in coolant temperature will necessitate a review of the other inverter circuitry, including the entire driver circuit, to determine what other new cooling requirements and/or component-related modifications may be necessary. 


\subsubsection{Cycle Lifetime of Power Modules and Wire Bonding}

One of the key causes of component degradation and wear out in power electronic packages is thermal fatigue. Thermal fatigue results from the mechanical stresses developed by the difference in expansion of $\mathrm{Si}$ and the metal used to mount the chip. These differences may cause the solder that connects the Si to the rest of the circuit to deform which may lead to cracks and the eventual failure of the circuit.

Temperature cycles and the corresponding range of temperatures are significant limiting factors in the lifetime of power electronics modules. The following equation [6] relates the temperature swing to the lifetime of the device in cycles where $\mathrm{N}_{\mathrm{m}}$ is the number of cycles, $\Phi$ and $a$ are packaging-related constants, and $\Delta \mathrm{T}$ is the temperature swing:

$$
N_{m}=\Phi \exp ^{(-a \Delta T)}
$$

For this equation, the values $4 \times 10^{6}$ and 0.06 are assumed for $\Phi$ and $a$, and these are believed to be typical approximate values for present-day Si-based power electronic modules. ${ }^{2}$ Based on these assumptions, Fig. 3.1 plots the number of allowable cycles to the temperature differential $(\Delta T)$.

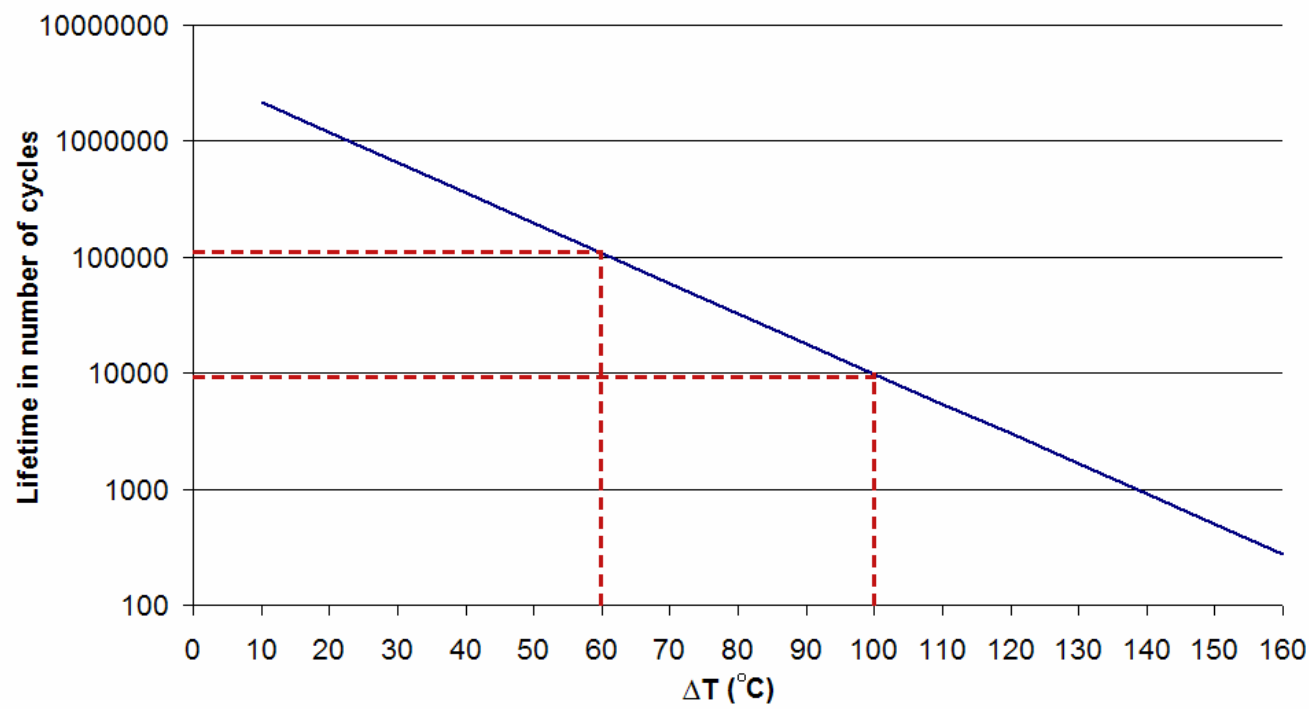

Fig. 3.1. Lifetime measured in number of cycles vs. $\Delta T$.

To determine the effects of $\Delta \mathrm{T}$ using $65^{\circ} \mathrm{C}$ and $105^{\circ} \mathrm{C}$ coolants, a $25^{\circ} \mathrm{C}$ minimum ambient temperature is considered. Allowing for maximum junction temperatures of $85^{\circ} \mathrm{C}$ and $125^{\circ} \mathrm{C}$ respectively, the resulting temperature swings above ambient are $60^{\circ} \mathrm{C}$ and $100^{\circ} \mathrm{C}$. From the graph, this corresponds to 110,000 and 9,900 cycles. This is more than a factor of 10 difference in the number of permissible cycles. By comparison, consider that 4 cycles per day in an actual vehicle for 15 year equates to 22,000 cycles. This suggests that a problem may exist at higher temperatures.

In addition, during vehicle operation the junction temperature may fluctuate many times between $105^{\circ} \mathrm{C}$ and $125^{\circ} \mathrm{C}$ as the motor is used and becomes idle. There are one million permissible $20^{\circ} \mathrm{C}$ cycles which

\footnotetext{
${ }^{2}$ These constants are well protected in the electronics industry. Therefore, example values must be used without any defendable source or reference.
} 
is twice the number needed assuming 100 cycles/day for 15 years. The two lower temperatures $\left(65^{\circ} \mathrm{C}\right.$ and $85^{\circ} \mathrm{C}$ ) create the same $20^{\circ} \mathrm{C}$ cycles and same conclusion.

This brief analysis is intended to simply illustrate that there may be a significant potential for a solderrelated fatigue issue that would limit the lifetime below 15 years if the use of a high-temperature coolant is implemented. A more rigorous analysis using better substantiated packaging constants is needed.

The long-term integrity of bond wires in the packaging of power electronic devices is also a concern at high temperatures. In recent years, the reliability of wire bonding has benefited from accelerated power cycling tests, analyses of the failure mechanisms, and improvements in material and bonding technology. This work has helped to identify failure mechanisms such as wire corrosion, heel cracks, bond lift-offs, and reconstruction of Al-metallization on the wafers. Industry and ORNL researchers are interested in eliminating wire bonds, if possible, and relying instead on pressure connections and/or soldering to copper pads.

The following are some examples of innovations being investigated for improved reliability of bond wires at elevated temperatures:

- New wire compositions

- Improved shapes of bonding tools

- Improved bonding parameters

- Thick-film metallization of Si-carbon ( $\mathrm{SiC}$ ) chips and leads

- Introduction of new protective coatings

\subsubsection{Inverter/Converter Barriers}

The assessment for high-temperature power electronics did not reveal any serious barriers, except for the use of conventional Si-based power electronics. This section provides a listing of what might best be characterized as weak barriers for the cooling of the inverter and converter subsystems at $105^{\circ} \mathrm{C}$. This follows discussions of the thermal performance of trench IGBTs and the potential for thermal fatigue and wire bonding failures in the power electronics device packaging.

The following describes both potential barriers for the inverter/converter and certain design considerations that merit mentioning:

1. As expected, conventional Si-based materials and power device packaging cannot support the use of a high-temperature coolant since junction temperatures will increase to $\sim 150^{\circ} \mathrm{C}$.

2. Recent literature [4] indicates that new $600 \mathrm{~V}$ IGBTs, using a trench MOS-top-cell with ultra-thin $70-\mu \mathrm{m}$ wafer technology, may be qualified for $175^{\circ} \mathrm{C}$ junction temperature, but the maximum operating temperature under switching conditions is reduced to $150^{\circ} \mathrm{C}$. Because $150^{\circ} \mathrm{C}$ is much better than $125^{\circ} \mathrm{C}$ and most likely adequate based on development efforts, the thermal derating issue is a design consideration.

3. There appears to be a significant potential for a solder-related fatigue issue that would limit the lifetime of IGBTs below 15 years if the use of a high-temperature coolant is implemented. This must be further investigated so that appropriate high-temperature solders, sintering, or other known technologies are employed. 
4. The cooling requirements of the inverter driver board must be thoroughly evaluated and/or certain driver circuit components may have to be upgraded to maintain reliability/expected life at elevated temperatures.

\subsection{THERMAL ASSESSMENT OF HIGH-TEMPERATURE DC-LINK CAPACITORS}

The capacitors used at the high voltage (HV) dc-link-to-inverter interface are of interest since, within the bounds of current technology, it is very challenging to manufacture capacitors that provide adequate ripple current at the elevated temperatures. This is certainly less of an issue for inverters placed in the passenger compartment as Honda does in its HEV line.

A review of articles by automotive manufacturers of elastomers, fluoroelastomers, plastic resins, and polymeric materials in general, make it abundantly clear that materials designed for use in engine compartments must be able to survive temperatures in the range of $140-160^{\circ} \mathrm{C}$, and material testing at $210^{\circ} \mathrm{C}$ and higher have become common. There have been many studies performed to identify engine compartment temperatures; however, these have only served to show (1) there is much variability depending on exact location, (2) there are typically large air stagnation zones, (3) temperature varies widely, and (4) the hottest conditions exist after a car is turned off (not generally applicable for capacitor operation). For an operating vehicle, the worse-case temperature will be considered to be $140^{\circ} \mathrm{C}$.

An engine compartment temperature of $140^{\circ} \mathrm{C}$ is considered applicable in the inverter design where a coolant-filled cold plate covers the base of a fully enclosed aluminum case in which the dc-link capacitor is housed. The cold plate is effective in moderating the capacitor temperature even though hot components are bolted to the cold plate surface and effectively cover it (see Section 2.3). Adopting a $105^{\circ} \mathrm{C}$ inverter coolant loop will increase the temperature of all the components in the casing including the capacitor. There is also the potential for active capacitor cooling in some future HEV design. This section seeks to identify all significant design barriers and how capacitor specifications and sizing may be affected.

Although many types of dielectrics exist, polymer film capacitors are generally produced with polypropylene, polyester, polycarbonate, or polystyrene. The temperature effects of these dielectrics result in changes in the capacitance, dissipation factor (DF), and lifetime of film capacitors. High temperatures limit the available ripple current levels. Alterations in capacitance and DF play a large role in the amount of power dissipated and ultimately the efficiency of the capacitor.

The base-case Prius, dc-link, polymer-film capacitor module contains the following three capacitors:

$1130 \mu \mathrm{F} @ 600 \mathrm{Vdc}$ for the inverter dc link

$282 \mu \mathrm{F} @ 600 \mathrm{Vdc}$ for the converter

$0.1 \mu \mathrm{F} @ 700 \mathrm{Vdc}$

Even in a $65^{\circ} \mathrm{C}$ system, the present technology can barely meet this high-temperature application with acceptable volume, mass, cost, and reliability/lifetime. Highlighting this fact, the Prius capacitor module has a mass of $3.1 \mathrm{~kg}$ (almost $7 \mathrm{lbs})$. 


\subsubsection{Lifetime [7]}

The lifetime of a capacitor is based on the operational temperature. For every $10^{\circ} \mathrm{C}$ that the maximum temperature is exceeded in continuous use, the lifetime of the capacitor falls by a factor of 2 . This is represented by the following equation:

$$
\begin{gathered}
\frac{L_{2}}{L_{1}}=\frac{V_{r}}{V_{o}} * 2^{x} \\
x=\frac{T_{m}-\left(T_{a}+\Delta T\right)}{10}
\end{gathered}
$$

where $V_{r}$ is the maximum rated voltage, $V_{o}$ is the operational voltage, $T_{m}$ is the maximum-rated temperature, $T_{a}$ is the ambient temperature, and $\Delta T$ is the temperature rise induced by ripple current. Using this equation and assuming that the thin film capacitors are operated at the maximum-rated voltage and that no additional heat is produced by the ripple current, Fig. 3.2 relates temperature to lifetime for polyethylene, polyester, polycarbonate, and polystyrene film capacitors. Since polyester and polycarbonate capacitors have the same maximum-rated temperatures, their plotted lines coincide exactly.

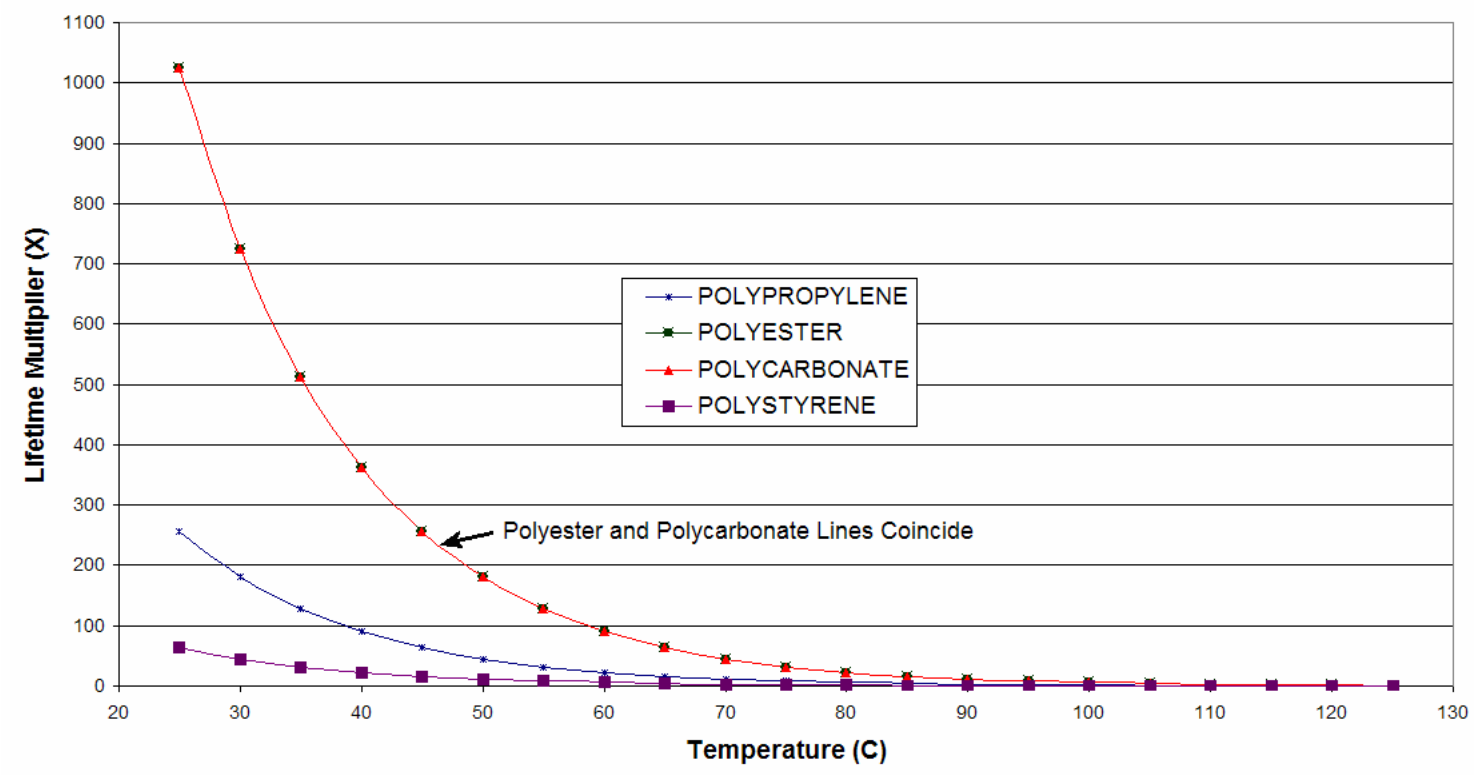

Fig. 3.2. Capacitor lifetime multiplier vs. temperature.

\subsubsection{Power Dissipation [8]}

The amount of power dissipated across a capacitor will provide a direct indication of the efficiency of the capacitor in relation to temperature. The power dissipated across a capacitor can be determined through the following equation.

$$
P=V_{A C}^{2} * 2 \pi f * C * D F
$$


where $V_{a c}$ is the root-mean square (RMS) of the ripple voltage across the capacitor, $f$ is the frequency of the voltage, $C$ is the capacitance, and $D F$ is the dissipation factor. Determining the power dissipation in terms of temperature requires that a relationship of capacitance and temperature and $D F$ and temperature be developed first.

Several manufacturers have performed tests that relate the change in capacitance to temperature. Figure 3.3 shows capacitance change vs. temperature for polypropylene, polyester, polycarbonate, and polystyrene capacitors. The plot shows very clearly how polyester capacitors exhibit a considerable increase in capacitance as temperature increases. In contrast, polypropylene capacitors exhibit a decrease in the capacitance as temperature increases. Polycarbonate and polystyrene capacitors exhibit smaller decreases in capacitance as temperature increases.

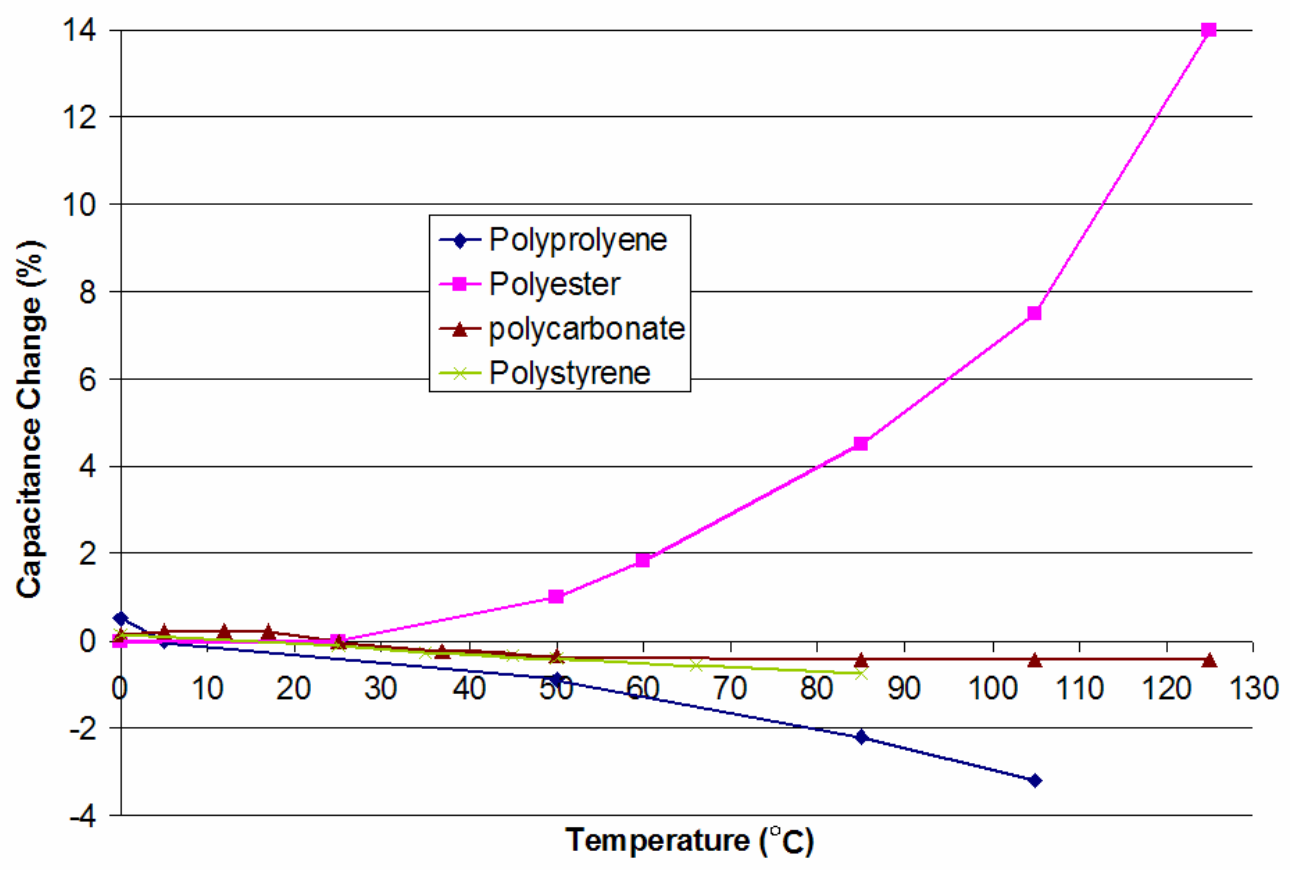

Fig. 3.3. Percentage of capacitance change vs. temperature.

Akin to capacitance changes in temperature, manufacturers have also performed tests on the $D F$ vs. temperature. The plot in Fig. 3.4 relates the $D F$ of polypropylene, polyester, polycarbonate, polystyrene to temperature. The plots show that temperature has little effect on the $D F$ of polypropylene, polycarbonate, and polystyrene, but has a significant effect on polyester. At higher temperatures, polyester exhibits a substantial rise in $D F$ with increases in temperature and this will significantly increase power dissipation at elevated temperatures. 


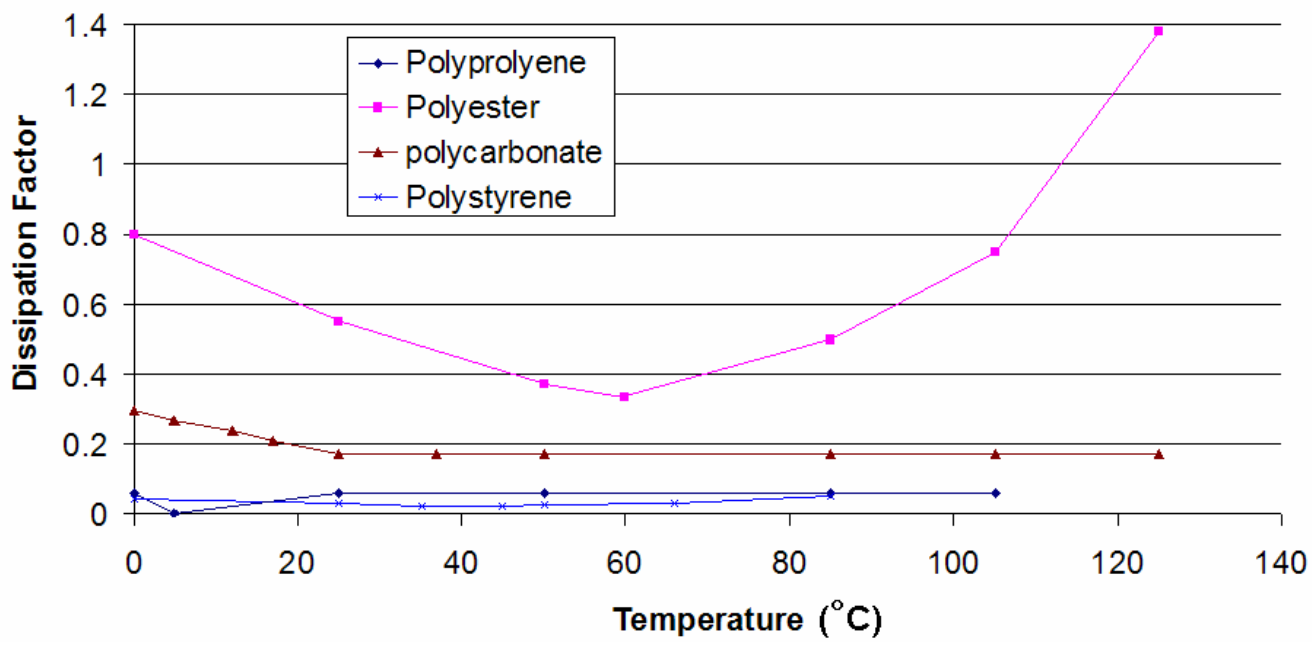

Fig. 3.4. Capacitor DF vs. temperature.

Using the knowledge gathered concerning the change in capacitance and $D F$ relative to temperature and using the equation developed at the beginning of this section, the plot in Fig. 3.5 relates the power dissipation to temperature. For calculation purposes, the assumption is made that the RMS ripple voltage is fixed at $20 \mathrm{~V}$ and the capacitance is $500 \mathrm{uF}$ at $25^{\circ} \mathrm{C}$. The plots indicate that temperature has little effect on polycarbonate, polypropylene, and polystyrene, but has a significant effect on polyester film capacitors.

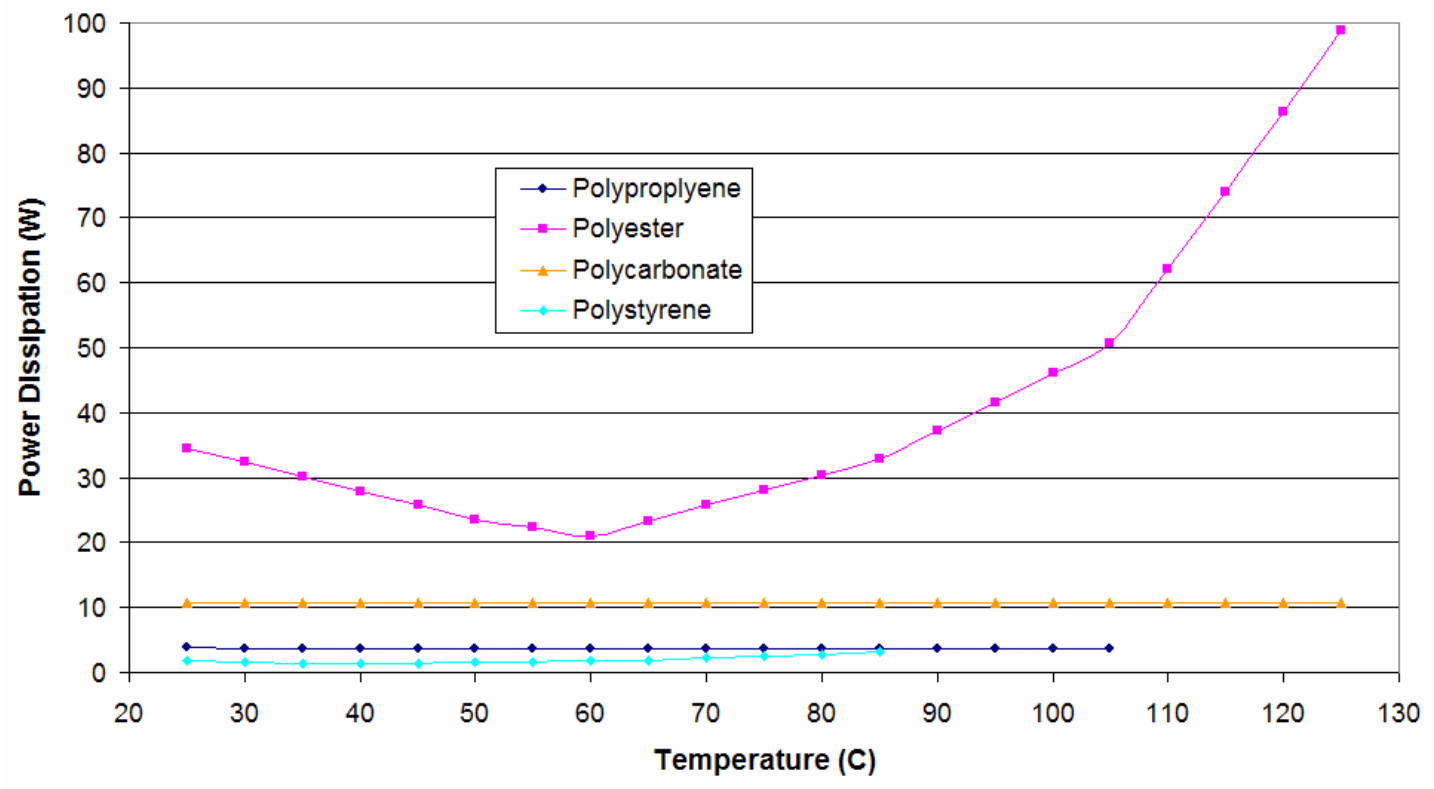

Fig. 3.5. Capacitor power dissipation vs. temperature.

\subsubsection{Maximum Ripple Current [9]}

HEV inverters must utilize high-capacitance at the HV dc input (across the dc link). These capacitors must be rated to withstand required ripple current. However, this rating decreases with increasing temperature. Because temperatures are projected to reach at least $125^{\circ} \mathrm{C}$ in the semi-cooled, Prius-like 
housing, the capacitor ripple current specification must be adjusted accordingly. In practice, this translates to an increase in not only the ripple current specification, but also physical size. In the case of the Prius, the modular polymer film capacitor takes up a significant portion of the volume inside the inverter/converter housing as indicated in Fig. 3.6.
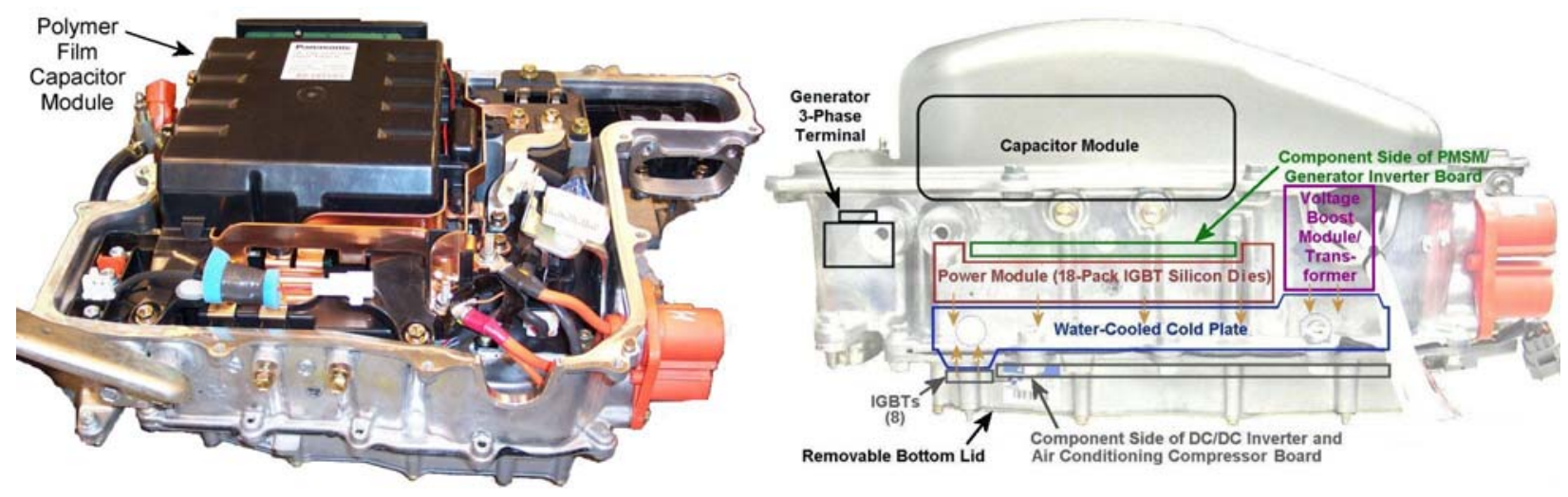

Fig. 3.6. Modular capacitor position and size in the Prius inverter/converter casing.

The amount of power dissipated across a capacitor is given as

$$
P=V_{A C}^{2} * 2 \pi f * C * D F=\frac{I_{A C}{ }^{2}}{2 \pi f * C} * D F .
$$

The maximum heat removal capacity is

$$
P=\frac{\Delta T}{R_{t h}} .
$$

Solving these two equations for the current ripple

$$
I_{A C}=\sqrt{\frac{\left(T_{R}-T_{A}\right) * 2 \pi f * C}{R_{t h} * D F}} .
$$

Assuming that a $500 \mathrm{uF}$ capacitor has a case thermal resistance, $\mathrm{R}_{\mathrm{th}}$, of $130 \mathrm{~W} /{ }^{\circ} \mathrm{C}$ and that the capacitor is operated at a $5 \mathrm{kHz}$ inverter switching frequency at rated temperature, the plots in Fig. 3.7 show the maximum available ripple current of the capacitor vs. temperature for polymer film and ceramic capacitors. 


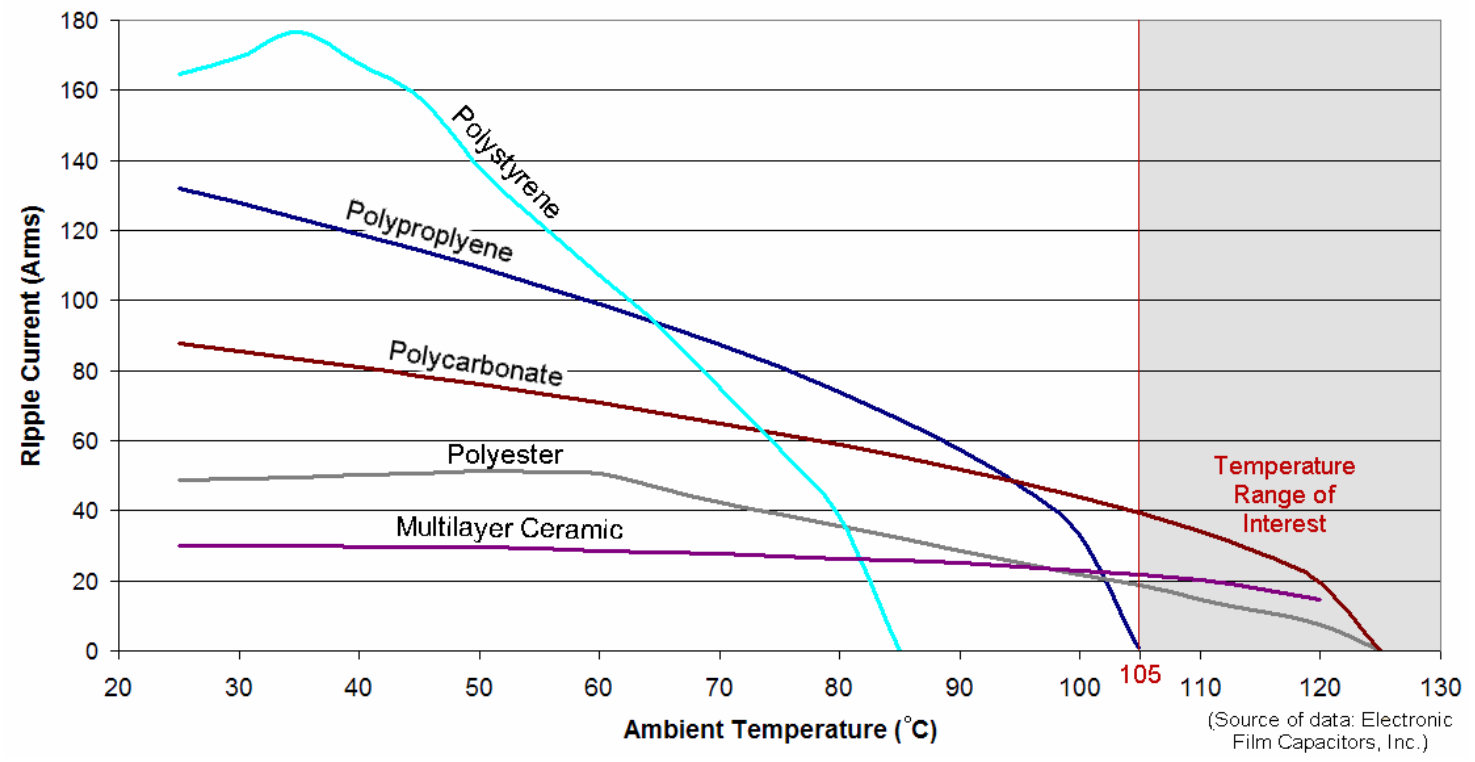

Fig. 3.7. Ripple current vs. ambient temperature for high-temperature capacitors.

Clearly, the adverse affect of temperature on ripple current is a serious issue. Figure 3.7 shows that at temperature $>80^{\circ} \mathrm{C}$, many of the rates of decrease worsen (downward turn) before approaching $0 \mathrm{~A}$. Based on this catalog data, even the polycarbonate, polyester, and ceramic capacitors do not appear to be of any potential use within the shaded range of interest. This leads to the question of what capacitors are being developed in laboratories or in the process of entering into production. Unfortunately, products in development are shrouded in secrecy and details are considered to be proprietary. This has provided a serious obstacle to the assessment of high-temperature capacitors.

\subsubsection{Availability of Capacitors and Related Barriers}

Although plots have been provided in previous sections showing the theoretical effects of temperature on capacitor lifetime, power dissipation, and maximum ripple current, the most pertinent determinations to be made in this analysis are (1) what high-temperature capacitors are available both now and near-term from capacitor vendors that meet voltage and current requirements; and (2) what is known about the reliability, lifetime, and cost of these new products?

The assessment of dc-link capacitors has been impeded repeatedly by the protection of proprietary data, general manufacturer secrecy, and non-disclosure agreements. However, ORNL is able to report that a leading ceramic capacitor manufacturer produces a high-temperature capacitor for which the specifications are reportedly:

- Each module is rated $16 \mu \mathrm{F}, 400 \mathrm{~V}$ continuous

- $\mathrm{I}_{\text {ripple }}=25 \mathrm{~A}$

- The temperature rating is $125^{\circ} \mathrm{C} \max$

- The cost is $\$ 20 /$ module

Based on the required ripple current in an inverter, $\sim 7$ modules would be needed in parallel at a total cost of $\$ 140$ in large-quantity purchases. However, the $400 \mathrm{~V}$ limit is problematic since a $600 \mathrm{~V}$ rating for an appropriate margin in HEV systems that include a $500 \mathrm{~V}$ boost converter. Other, higher-cost 400V capacitors were reported, but there were no reports of $600 \mathrm{~V}$, high-temperature, inverter-grade capacitors 
being available other than prohibitively expensive Teflon capacitors. However, Semikron [10] reports that in the process of their development of a high-temperature inverter, they reached the conclusion that commonly available, $600 \mathrm{~V}$ capacitors can be used if 3 are placed in parallel. Using current film capacitor technology will result in increasing the volume, mass, and cost by a factor of 3 ; this is considered a serious penalty.

New capacitors with improved specifications and significantly lower-cost are expected in 1-2 years - or in 10 years - depending on which technical or industry source is consulted. Knowing the timeframe when suitable dc-link capacitors will become available is of very high value; however, accurately predicting the timing or knowing the accuracy of such predictions is virtually impossible. Experts have predicted breakthroughs in technology and pricing "in 1-2 years" for more than 10 years.

Even if a reasonably priced high-temperature capacitor entered the market today, meeting all electrical and thermal requirements, it would be necessary to take a close look at the claimed reliability, lifetime, and failure modes. This may require testing by the customer.

The design barriers for dc-link capacitors include the following:

1. Temperature increases in the dc-link capacitor application have a strong and detrimental effect on the ripple current specification for many types of polymer capacitors.

2. High-temperature $\left(125^{\circ} \mathrm{C}\right.$ or higher $)$ capacitors with adequate ripple current and a $600 \mathrm{~V}$ continuous rating can be found today by taking existing capacitors and using 3 in parallel. This approach triples cost and size which is a serious penalty and a major barrier. There is a need for low-cost, high-temperature capacitors and it is important that these be brought to the market soon.

3. The few $400 \mathrm{~V}$, high-temperature capacitors entering the market today have higher-than-desirable cost.

4. The reliability and lifetime of any newly released, high-temperature capacitors must be well established through testing before they are introduced into vehicles.

5. Ceramic capacitors have superior high-temperature performance when compared to polymer film capacitors; however, presently the cost is high and an unacceptable energetic and flammable failure mode exists.

6. Teflon capacitors have excellent high-temperature performance, but cost is clearly prohibitive.

\subsection{THERMAL ASSESSMENT OF A PMSM}

This section considers the potential effects of using a high-temperature coolant system for a HEV PMSM. The section begins by considering the most vulnerable components which include the PMs, stator winding insulation, and cooling oil, and then considers the PMSM subsystem as a whole. The subsystem assessment draws on (1) an analytical analysis of the effect of temperature on efficiency and (2) a physical assessment of current HEV PMSM designs supported by detailed thermal studies in order to identify a list of potential barriers.

The electrical assessment of a PMSM circuit is provided in Appendix B. The appendix considers the motor-circuit-level effects of temperature on residual flux density, back-electromotive force (emf), stator copper losses, and ultimately on electrical power efficiency. That assessment found that higher 
temperatures result in a very substantial $29 \%$ increase in losses due to temperature-induced changes in back-emf and stator winding copper losses. This would result in unacceptable temperatures for the stator insulation and PMs unless the cooling system was significantly improved and/or the size of the motor was increased to facilitate heat transfer. These findings will be included in the list of barriers at the conclusion of the PMSM assessment.

\subsubsection{Thermal Characterization of Magnets}

Industry today makes use of several different classes of PMs such as Alnico, ceramic, samarium cobalt $\left(\mathrm{Sm}_{\mathrm{x}} \mathrm{Co}_{\mathrm{y}}\right)$, and neodymium iron boron $(\mathrm{NdFeB})$.

The following is a brief overview of the four types of magnets $[11,12]$ :

The Alnico magnets are composed of metals such as aluminum, nickel, and cobalt. This type of magnet is characterized by excellent temperature stability, high residual induction, and superb strength. However, this type of magnet is difficult to machine and must be handled carefully to avoid demagnetization.

The ceramic magnet is the most commonly used. Ceramic magnets are composed of barium and strontium ferrite and tend to be brittle and hard to machine. These magnets offer low-cost while displaying excellent stability, high strength, and resistance to corrosion and demagnetization.

$\underline{\mathrm{Sm}}_{\underline{x}} \mathrm{Co}_{\mathrm{Y}}$ is a rare-earth magnet with outstanding magnetic properties including a large magnetic strength, high thermal stability, and excellent corrosion resistance. This magnet is well suited for applications demanding high magnetic strength in high temperature environments. Yet, these magnets can cost significantly more than $\mathrm{NdFeB}$ magnets and the availability of cobalt is limited [13].

$\underline{\mathrm{NdFeB}}$ magnets are the most powerful of all the magnets listed above and are made of advanced rare-earth materials. They provide high performance, resilience against demagnetization, and low cost. However, these magnets are extremely sensitive to temperature and susceptible to oxidation if not properly coated $[14,15]$.

Table 3.1 lists some of the properties of several PMs. The property, remanent induction, describes the natural strength of the PM while the intrinsic coercivity relates the ability of the material to withstand demagnetization. The energy product gives an indication of the sizing of the magnet, the larger the energy product, and the smaller size requirements of the magnet $[16,17]$. As evident from the table, $\mathrm{NdFeB}$ type magnets have the most desirable characteristics for high-power-density PMSMs.

Table 3.1. Properties of several PMs

\begin{tabular}{|c|c|c|c|}
\hline Material & $\begin{array}{c}\text { Remanent } \\
\text { Induction, T }\end{array}$ & Intrinsic Coercivity & $\begin{array}{l}\text { Energy Product, } \\
\mathrm{kJ} / \mathrm{m}^{3}\end{array}$ \\
\hline Sr Ferrite & 0.43 & 0.20 & 34 \\
\hline Alnico 5 & 1.27 & 0.05 & 44 \\
\hline Alnico 9 & 1.05 & 0.12 & 84 \\
\hline $\mathrm{SmCo}_{5}$ & 0.95 & 1.30 & 176 \\
\hline $\mathrm{Sm}_{2} \mathrm{Co}_{17}$ & 1.05 & 1.30 & 208 \\
\hline $\mathrm{Nd}_{2} \mathrm{Fe}_{14} \mathrm{~B}$ & 1.36 & 1.03 & 350 \\
\hline
\end{tabular}


NdFeB are frequently selected for HEV applications, including the Prius, due to their high magnetic strength and low cost. Unique Mobility (UQM), a major manufacturer and researcher of PM motors, also uses NdFeB PMs [13, 18-21]. Therefore, these magnets will be closely considered in this assessment.

As noted previously, $\mathrm{NdFeB} \mathrm{PMs}$ are highly sensitive to temperature. An increase in temperature reduces the magnetic strength linearly up to $100^{\circ} \mathrm{C}$ as follows [22]:

$$
B_{r}=B_{r A}+s\left(T-T_{A}\right)
$$

where $B_{r A}$ is the residual flux density at normal ambient temperature $T_{A}$ and $s$ is the slope of the $B_{r}$ temperature characteristic (for $\mathrm{NdFeB}$ this tends to be $-0.1 \%$ per ${ }^{\circ} \mathrm{C}$ ). Above $100^{\circ} \mathrm{C}$, the magnetic field strength begins to fall more rapidly as indicated in Table $3.2[17,18]$.

Table 3.2. Characteristic of Delco Remy MQ2 ${ }^{1} \mathrm{NdFeB}$ magnets

\begin{tabular}{|l|c|}
\hline Residual induction & $0.8 \mathrm{~T}$ \\
\hline Intrinsic coercive force & $1.43 \mathrm{ma} / \mathrm{m}$ \\
\hline Temperature coefficient of $\mathrm{Br}$ to $100^{\circ} \mathrm{C}$ & $-0.10 \%$ \\
\hline Temperature coefficient of $\mathrm{Br}$ to $125^{\circ} \mathrm{C}$ & $-0.11 \%$ \\
\hline Temperature coefficient of $\mathrm{Br}$ to $175^{\circ} \mathrm{C}$ & $-0.15 \%$ \\
\hline
\end{tabular}

For an NdFeB PM with the above characteristics, Fig. 3.8 shows the reduced strength of the magnet in per unit form vs. temperature. For instance, it is estimated that there will be a $20-30 \%$ reduction in flux strength for motor operation at the higher coolant temperature as $\mathrm{PM}$ temperature approaches $200^{\circ} \mathrm{C}$. This temperature-induced effect represents a barrier and is very significant to this study. This reduction in magnetic field strength due to temperature is reversible in that the magnetization will return to the original value once the temperature is decreased.

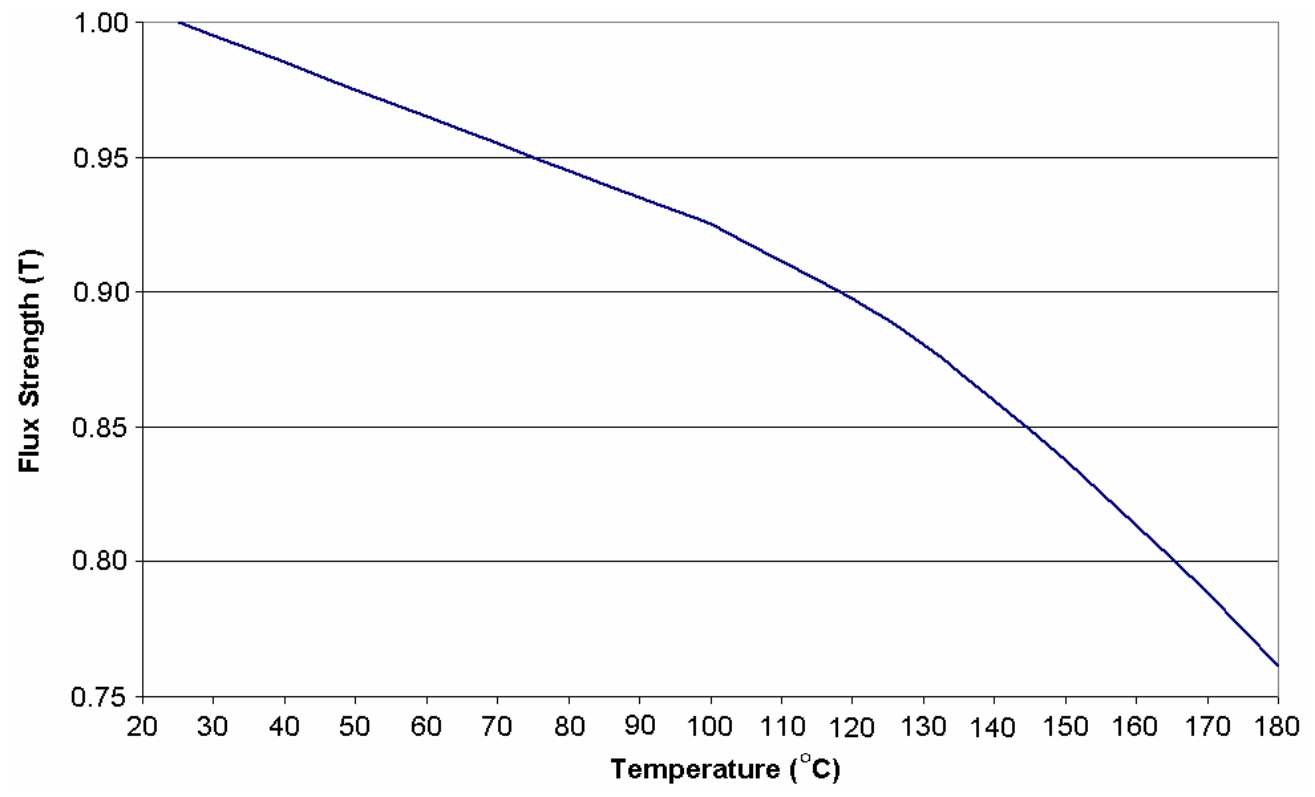

Fig. 3.8. Flux strength of a selected NdFeB magnet vs. temperature. 
If the operating temperature of the motor exceeds a certain critical temperature, irreversible demagnetization of the magnet will result [20]. This critical temperature is $\sim 150^{\circ} \mathrm{C}$ for many types of $\mathrm{NdFeB}$ magnets, but $220^{\circ} \mathrm{C}$ for the particular type of $\mathrm{NdFeB} \mathrm{PM}$ selected for the Prius [23]. However, the reversible, temperature-induced reduction in field strength is more significant since the motor performance (i.e., shaft power) will be significantly reduced at temperatures that will be frequently reached during vehicle operation (assuming a $105^{\circ} \mathrm{C}$ coolant).

\subsubsection{Stator Winding Insulation}

Magnet wire used in many applications today is inverter spike resistant (ISR). This wire has a Class $\mathrm{H}$ temperature rating and exhibits excellent resistance to damage from HV spikes that commonly result from rapidly changing pulse-width modulation (PWM) currents in inductive circuits.

Motor wire insulation is a well-developed technology that is not expected to change significantly in the next several years. That is not to imply that major strides have not been made in the last 25 years. Today's motors operate at significantly higher temperatures while meeting 20,000 hr lives or greater. The most common types of insulation, in order of increasing quality, are Class A, Class B, Class F, and Class $\mathrm{H}$. These insulations are rated for maximum temperature in $25^{\circ} \mathrm{C}$ increments as indicated in Fig. 3.9. Less common insulations are available such as Class $\mathrm{S}\left(240^{\circ} \mathrm{C}\right)$ and Class $\mathrm{C}$ (over $\left.240^{\circ} \mathrm{C}\right)$; however, the use of these would create a cost increase which is most likely avoidable based on the assessment below.

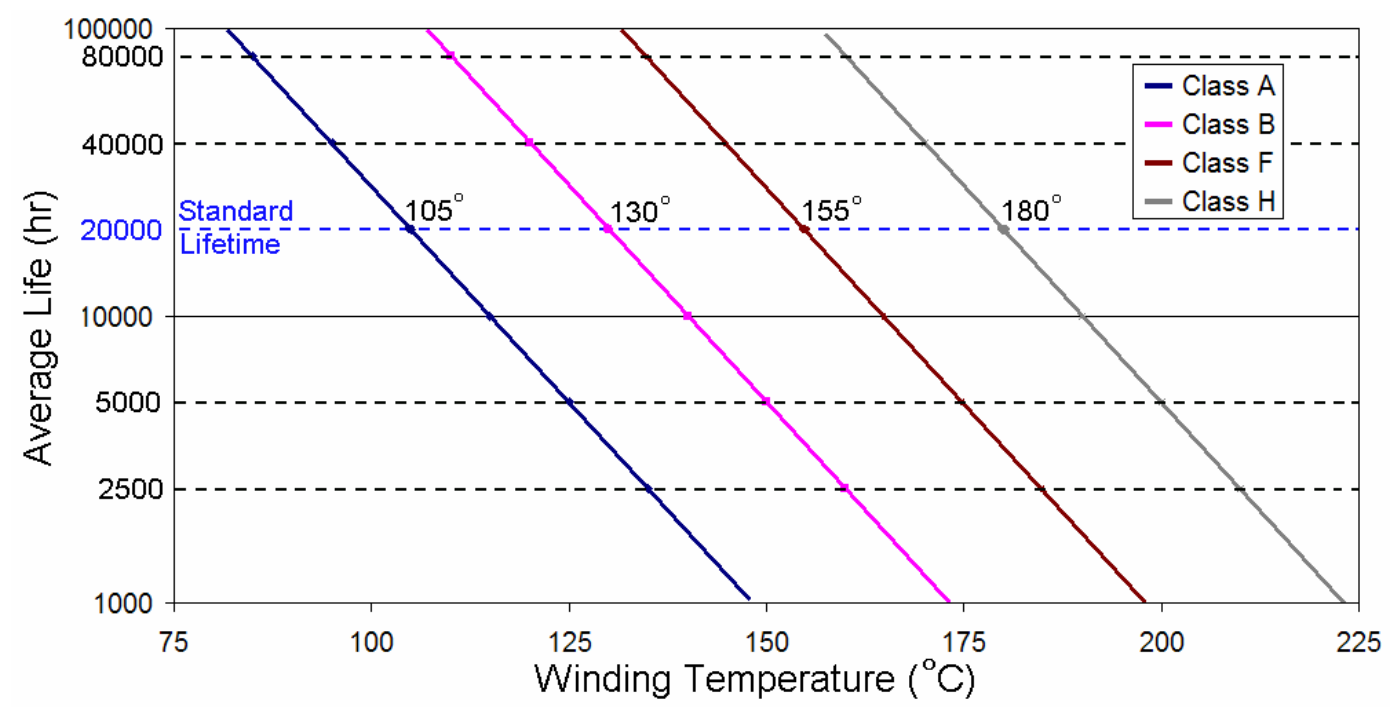

Fig. 3.9. Average motor insulation life vs. winding temperature for four insulation types.

For HEV applications, it is essential to fully understand the duty cycle and rate of accrued time on the motor when estimating motor insulation life. For instance, the Prius is considered to be a "strong hybrid" since the motor is relied upon $100 \%$ for accelerations from a full stop. It is also used to assist the engine for accelerations and high torque demands such as passing vehicles at highway speeds and for driving up a grade. Table 3.3 shows an estimate of the required number of hours that may be expected from the motor during a 15-year period. The example numbers reflect heavy usage of the vehicle with an accrued 240,000 miles. If one assumes that the fraction of time when the motor temperature is hot (near or above $180^{\circ} \mathrm{C}$ ) to be 0.75 , then the number of life-shortening hours on the insulation is $5100 \mathrm{hrs}$. This high fraction would reflect stop-and-go city driving rather than highway usage where the motor may be seldom used. The $5100 \mathrm{hrs}$ is far below the $20,000 \mathrm{hr}$ standard for motor insulation life. Referring to Fig. 3.9, 
this would permit the use of Class $\mathrm{H}$ insulation at $200^{\circ} \mathrm{C}$ instead of the $180^{\circ} \mathrm{C}$ standard. If this does not prove to be adequate, Class $\mathrm{C}$ insulation would provide well in excess of $240^{\circ} \mathrm{C}$.

Table 3.3. Estimate of life-shortening hours accrued during 15 years of city driving

\begin{tabular}{|c|c|c|c|c|c|}
\hline $\begin{array}{c}\text { Daily } \\
\text { Vehicle } \\
\text { Operation, } \\
\text { hrs/day }\end{array}$ & $\begin{array}{c}\text { Days in } \\
\text { a Year }\end{array}$ & $\begin{array}{c}\text { No. of } \\
\text { Years }\end{array}$ & $\begin{array}{c}\text { Fraction of Vehicle- } \\
\text { Operation Time When The } \\
\text { Stator Insulation is at a } \\
\text { Life-Shortening Temp }\end{array}$ & $\begin{array}{c}\text { Accrued Life- } \\
\text { Shortening } \\
\text { Hours in } \\
\text { 15 years }\end{array}$ & $\begin{array}{c}\text { Accrued Miles } \\
\text { in the 15 years } \\
\text { a 35 mph }\end{array}$ \\
\hline 1.25 & 365 & 15 & 0.75 & 5100 & 240,000 \\
\hline
\end{tabular}

\subsubsection{PMSM Test Data and Physical Assessment}

Section 2.1 introduced the Prius low-temperature HEV subsystem design for the vehicle coolant loops, the motor, the inverter/converter package, and the dc-link capacitor. Sections 3.3.1 and 3.3.2 considered the effects of increasing temperature on the magnets and stator insulation.

Thus far, the assessment of the PMSM has reached the following conclusions:

- The PMs have a critical-temperature limit of $220^{\circ} \mathrm{C}$ and there will be a $15-20 \%$ reduction in flux strength for motor operation at the higher coolant temperatures (Section 3.3.1).

- The stator insulation has a high-temperature limit up to $208^{\circ} \mathrm{C}$ or $224^{\circ} \mathrm{C}$ using Class $\mathrm{C}$ insulation at a higher cost (Section 3.3.2).

- Based on a PMSM circuit model (Appendix B), higher temperatures result in a very substantial $29 \%$ increase in peak power losses due to temperature-induced changes in back-emf and stator winding copper losses.

This section moves to the full subassembly level and considers test data obtained from operation of the Prius PMSM. These data are pre-existing, they are not the result of tests designed specifically to evaluate a high-temperature coolant system. As a result, this section must seek to deduce what pertinent information, if any, might exist. For instance, by making use of the results obtained in past thermal control testing at temperatures close to $65^{\circ} \mathrm{C}$ and $105^{\circ} \mathrm{C}$, it may be possible to improve the accuracy of predicted effects of a $105^{\circ} \mathrm{C}$ coolant.

\subsubsection{Temperature margin for PMs based on parametric model}

ORNL testing of the Prius hybrid systems has not included direct thermal measurements of the rotor/magnet assembly. However, in the 2004 thermal study [1], thermal data was used in a threedimensional conduction heat transfer model, HEATING 7.3, to generate predicted temperature profiles for various motor components.

Figure 3.10 shows examples of predicted temperature profiles for the Prius motor rotor and magnet components based on the heat conduction model. Although the actual V-oriented geometry of the 2004 model magnets was not carried over for the sake of a smaller, more robust model that could operate more quickly, the thermal results are believed to be essentially the same. The prediction shows that for the $50^{\circ} \mathrm{C}$ cooling case and a near-maximum permissible stator temperature of $162^{\circ} \mathrm{C}$, the steady-state temperature in the magnets is $\sim 4^{\circ} \mathrm{C}$ lower, $158^{\circ} \mathrm{C}$. These conditions were attained at $900 \mathrm{rpm}$ and $\sim 161 \mathrm{Nm}$ shaft load. 


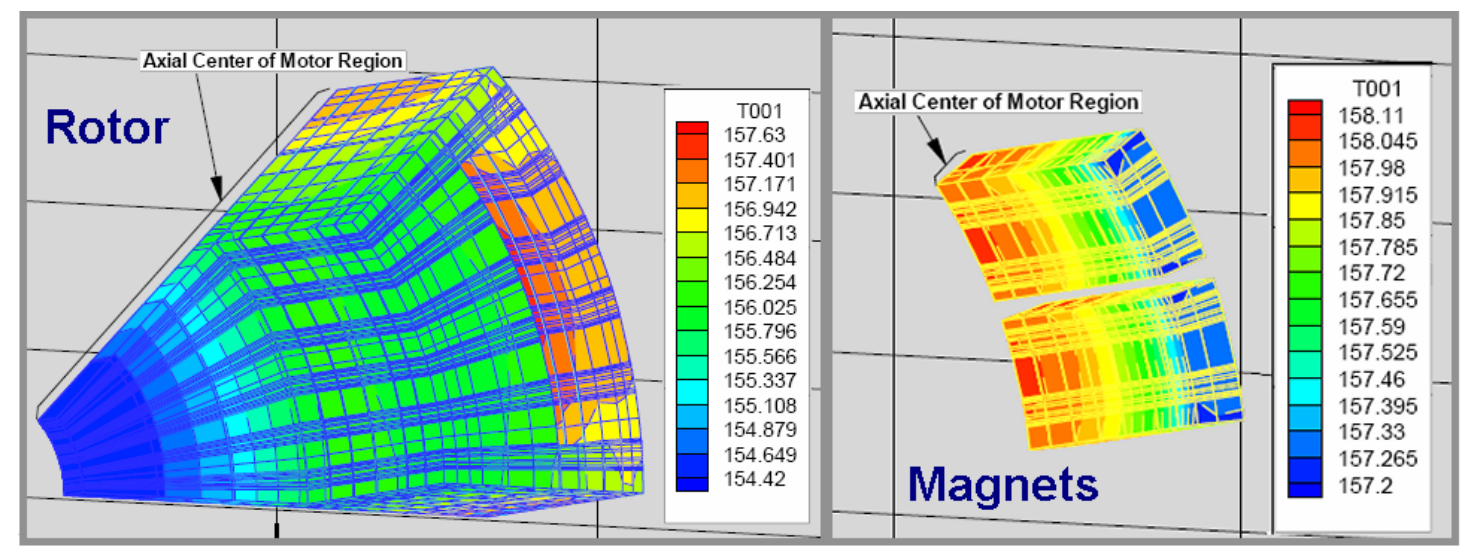

Fig. 3.10. Predicted temperature profiles for the Prius rotor and magnets $\left(50^{\circ} \mathrm{C}\right.$ cooling).

\subsubsection{Continuous power derating in a PMSM at two coolant temperatures}

The 2004 thermal control tests [1] demonstrated that the Prius PMSM was able to operate continuously at $20 \mathrm{~kW}$ if the stator temperature was not allowed to exceed $167^{\circ} \mathrm{C}$. Other defined conditions/restrictions were a coolant temperature of $50^{\circ} \mathrm{C}, 1200 \mathrm{rpm}$ shaft speed, and $210 \mathrm{~V}$ line-to-line. When the coolant temperature was increased to $105^{\circ} \mathrm{C}$ and other operating conditions maintained the same, the motor had to be derated to $15 \mathrm{~kW}$ (a $25 \%$ decrease in continuous power). Had the original temperature been $65^{\circ} \mathrm{C}$ instead of $50^{\circ} \mathrm{C}$, it is estimated that the decrease in power would have been $\sim 20 \%$.

The $\sim 20 \%$ decrease in continuous power was the result of increasing the coolant temperature while maintaining the stator temperature near $167^{\circ} \mathrm{C}$. All or part of the $\sim 20 \%$ derating could be mitigated if the temperature of the stator was allowed to climb to a substantially higher maximum. The main consideration would be the loss of magnetic strength, which would either lead to a loss in motor performance and/or an attempt to compensate with higher motor current (thus compounding the thermal control problem).

Allowing the stator temperature to reach substantially higher temperatures will result in the oil coolant also reaching a similar temperature when flung onto the windings by the rotor. Thus, a synthetic oil must be selected with a sufficiently high flash temperature.

\subsubsection{Design approach for the PMSM}

This section does not add to or more fully develop the conclusions reached thus far pertaining to the PMSM, but rather it more fully characterizes the thermal performance of the PMSM in support of proposed approaches that may be taken in the design of a high-temperature motor.

Figure 3.11(a) shows the water/glycol loop that cools the hybrid components in the Prius. The generator (not shown) is located directly behind the motor. After providing cooling to the inverter and passing through an electric pump, the coolant enters the generator casing to provide cooling, and then through separate hose fittings, into the motor casing. Figure 3.11(b) shows the modestly sized heat exchanger located above the motor and in close proximity to the generator. The stator heat removal process in the PMSM uses oil slinging as indicated in Fig. 3.11(c). 


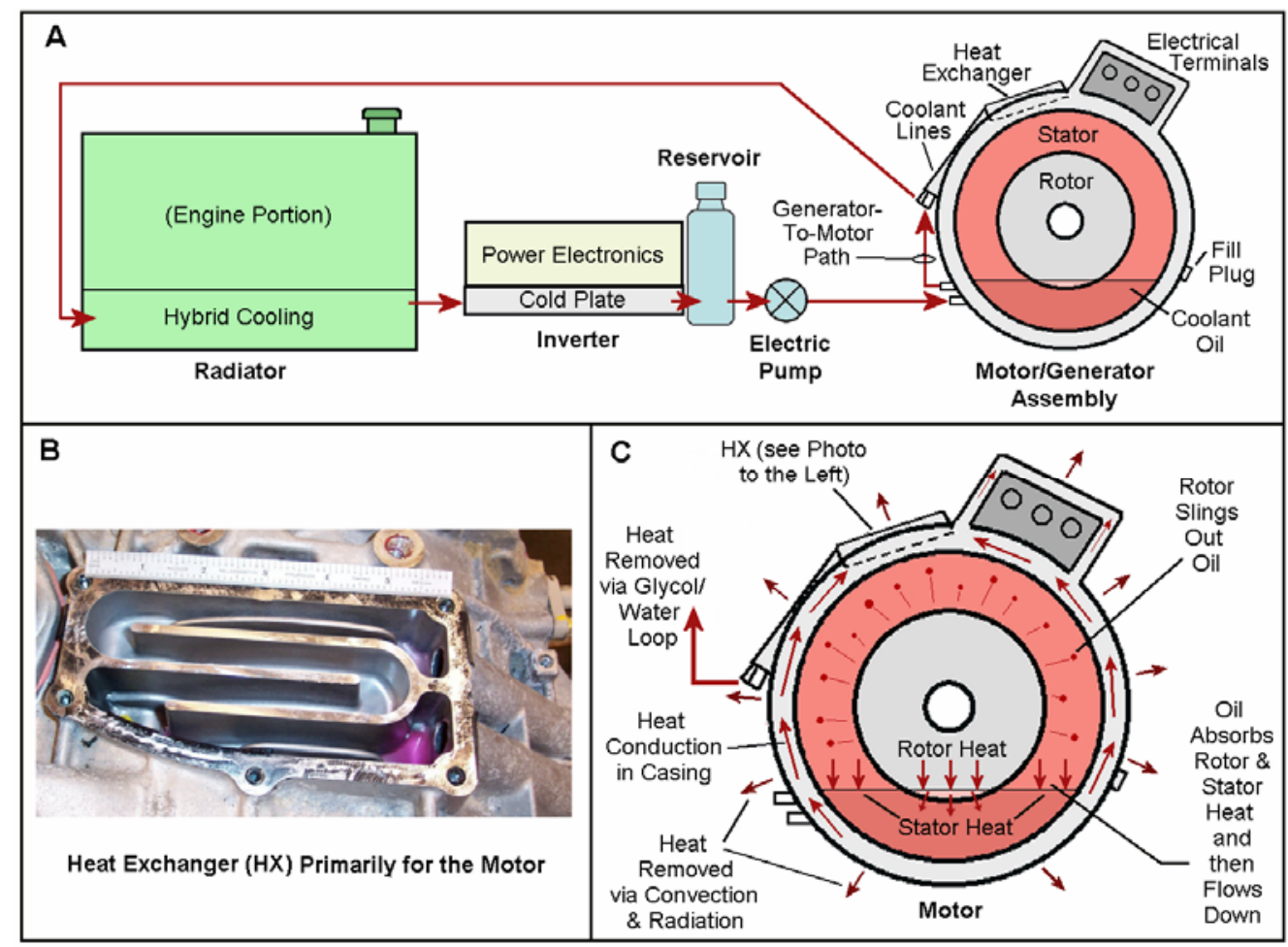

Fig. 3.11. Prius cooling loop and heat flow for the hybrid subsystems.

The water/glycol heat exchanger is assessed as follows in the summary in ORNL's 2004 thermal study [1]:

"These experimental results, along with the modeling studies presented here, indicate that the performance of the motor can be improved by more effectively cooling the oil. The experimental results... indicate a weak coupling between oil temperature and coolant temperature. More effective cooling of the oil would enable the motor to operate at higher load levels without overheating the windings."

Based on the above, it is proposed that, in the interest of controlling magnet temperature, the increase in the temperature of the coolant system should be accompanied by enhancements in the heat exchanger design. This would involve relocating it to be adjacent to the oil bath at the bottom of the motor and increasing its size. Another alternative would be to encircle the stator with a cooling jacket. The following discussion will provide additional support for these design approaches.

Efficiency mapping test data obtained early in 2006 [2] shows that the Prius motor stator experiences rapid heating during short-term operation approaching $40-50 \mathrm{~kW}$. Figure 3.12 shows the time-based thermal plot of the 2004 Prius motor during a 20-minute gradual current increase and after a sudden current decrease. All the plotted lines are temperature with the exclusion of the motor current plot. As expected, the stator winding temperature rises the most rapidly and to the highest temperatures followed by the cooling/transmission oil, which comes in direct contact with the stator and rotor. Motor casing temperatures are cooler than the oil temperature by varying degrees depending on location. 


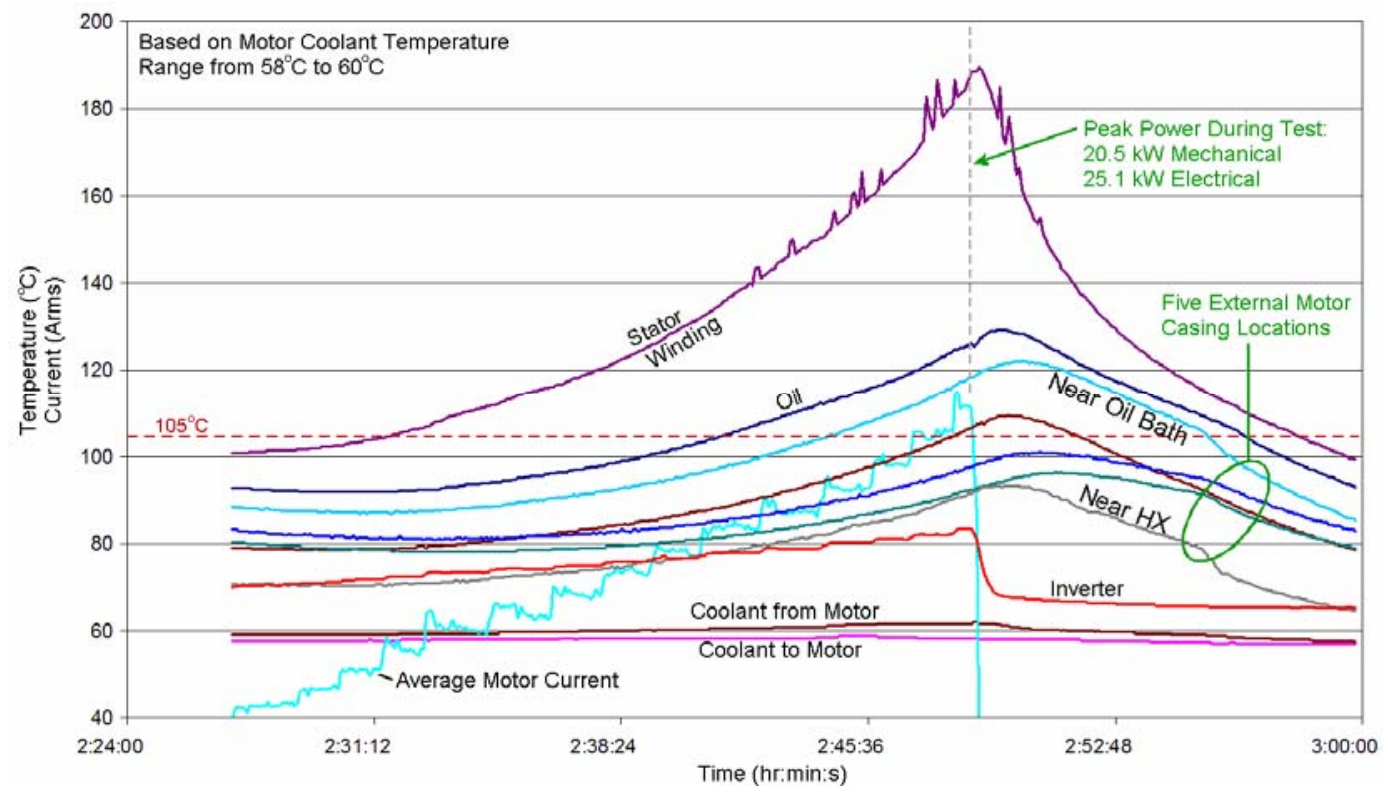

Fig. 3.12. Thermal time-profile of Prius motor during current increase and decrease.

The plots show that the hottest casing temperature is at the bottom where the oil is pooled; the coolest location is close to the heat exchanger. (The inverter is cooler than the casing, as expected, since the coolant flows through the inverter immediately before the generator/motor casing. The inverter temperature drops immediately after the current drop due to the highly efficient cold plate design.) The motor coolant temperature is well below the motor casing temperature and the thermal excursion clearly evident in all areas of the motor is barely discernable in the "coolant from motor" plot. These two observations are expected since the cooled water/glycol mixture is continuously entering the heat exchanger.

It is certain that if the motor coolant had actually been $46^{\circ} \mathrm{C}$ higher $\left(105^{\circ} \mathrm{C}\right.$ instead of $\left.\sim 59^{\circ} \mathrm{C}\right)$, many of the plotted temperatures would have been significantly higher. This is due primarily to the high coolant temperature that would raise the temperature floor, even when the motor is not powered. Because the temperatures would be generally higher, the $105^{\circ} \mathrm{C}$ coolant would have significant periods of time when it would provide cooling instead of heating.

Figure 3.13 shows the general design approach for a PMSM cooled by $105^{\circ} \mathrm{C}$ coolant. Because the temperature floor is raised substantially, a design response is needed to lower and stiffen the temperature ceiling by making the heat exchanger, and possibly other components, more effective in responding to thermal excursions that occur during vehicle operation. 


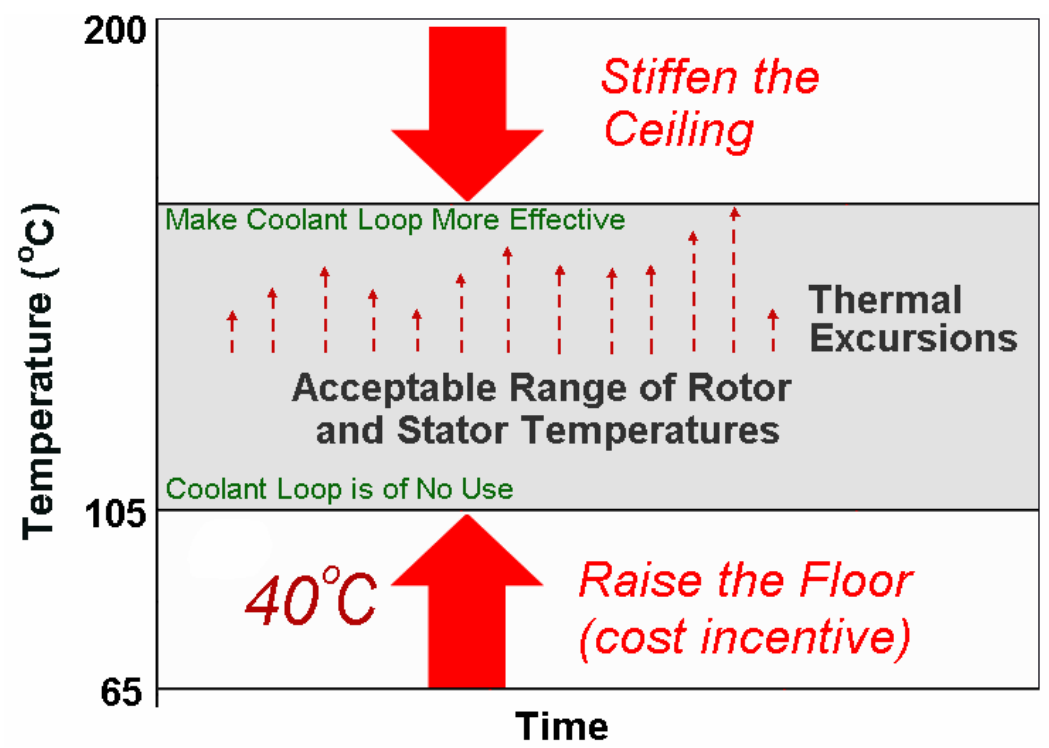

Fig. 3.13. General PMSM design approach applicable for high-temperature cooling.

\subsubsection{PMSM Barriers Resulting from Higher Coolant Temperature}

This section considers the findings of Section 3 and Appendix B to identify what barriers may exist to the development of a $\sim 55 \mathrm{~kW}$ (peak) PMSM that relies on a high-temperature cooling loop. Clearly, the main consideration is limiting the maximum temperatures primarily in the PMs and also in the stator winding insulation. This must be accomplished to ensure that the performance of the PMSM remains high and that the PMSM has an adequate (15-year) lifetime.

Before identifying design barriers, the following observations are made concerning an unmodified PMSM that is cooled with a $105^{\circ} \mathrm{C}$ cooling loop:

1. Heat will not be removed from the casing as effectively as in the case of a $65^{\circ} \mathrm{C}$ coolant design.

2. Because of (1), the oil temperature, stator temperature, and rotor temperatures will be higher.

3. There will be significant time periods when the $105^{\circ} \mathrm{C}$ coolant will be heating the motor casing.

4. There will also be times when the $105^{\circ} \mathrm{C}$ coolant will provide cooling due to (a) the temperature floor of the PMSM being raised and (b) motor operation in up to $140^{\circ} \mathrm{C}$ engine compartment temperature.

The following are the PMSM barriers:

1. The primary barrier for the PMSM is that the flux strength of the PMs will decrease $20-30 \%$ whenever the PMs are at elevated temperatures consistent with operation based on a hightemperature coolant. This will reduce PMSM/vehicle performance and/or require higher, compensating motor current. Higher motor current will compound the thermal control problem.

2. As discussed in Appendix B, higher temperatures result in a very substantial $29 \%$ increase in losses due to temperature-induced changes in back-emf and stator winding copper losses. This will result in unacceptable temperatures for the stator insulation and PMs unless the cooling system is significantly improved and/or the size of the motor is increased to facilitate heat transfer. Detailed thermal studies will be required to produce a high-temperature motor design.

3. During those times when heat flows from the motor to the coolant, the temperature gradient between the coolant and casing will be low, reducing the effectiveness of the heat exchanger. 
4. Due to increased stator winding operating temperatures, Class $\mathrm{H}$ insulation will be operated beyond its conventional limits. This may be acceptable based on total hours of operation at high temperatures, but some level of detailed verification/study may be needed.

5. Higher temperature stator insulation (Class C) can be used but at higher cost.

6. One design approach to better controlling PM temperature entails the design of a more effective water/glycol-coolant-to-oil heat exchanger. Increasing the size of the heat exchanger and locating it at the bottom of the PMSM are desirable approaches but will increase volume, mass, and cost. Encircling the stator with a cooling jacket is another option. These approaches are considered to be "a beginning" that must be followed by other, yet-undefined improvements.

7. The acceptability of raising coolant temperature can only be fully verified by selecting detailed candidate designs and performing thermal analysis and performance modeling. This will incur developmental costs.

\subsection{SYSTEM-LEVEL ASSESSMENT}

This section focuses more fully on the most decisive and pertinent design parameter, cost. In considering numerous design changes that must be or could be pursued to eliminate a dedicated, low-temperature cooling loop, it is important to weigh the cost requirements of each proposed design against the cost savings of eliminating the dedicated cooling loop.

The Prius uses a $\$ 480$ radiator $(2.05 \mathrm{~g}$ and $4.19 \mathrm{~L})$ that is partitioned to provide a low-temperature, $1.14 \mathrm{~L}$, dedicated coolant-loop radiator. This loop also uses a $\$ 142.0012-\mathrm{Vdc}$ electric pump (344g) and miscellaneous hoses. The elimination of this system may entail simply eliminating the partitioning in the radiator, eliminating the pump, and reconfiguring a few hoses. Table 3.4 shows the predicted cost savings. Using an un-partitioned radiator would save $\sim \$ 80$ and, with the elimination of the pump and two hoses, the total savings would be $\sim \$ 250.00$ based on the retail prices of new components and the wholesale cost would be $\sim \$ 187.50$, as indicated.

The manufacturer's per-unit-vehicle savings must be weighed against the per-unit costs of different design enhancements that enable high-temperature cooling. This can only be accomplished if (1) the needed high-temperature components are available for purchase and (2) the detailed configuration of the high-temperature subsystems, such as the PMSM, are known. The system-level evaluation is further described and summarized in Section 4.

Table 3.4, Itemized listing of costs of eliminated components

\begin{tabular}{|l|c|c|}
\hline Eliminated Components or Features & $\begin{array}{c}\text { Cost Savings, } \\
\mathbf{S}\end{array}$ & $\begin{array}{c}\text { Source Used as Basis of } \\
\text { Estimation }\end{array}$ \\
\hline Electric pump & 142 & Toyota of Knoxville \\
\hline Partitioning of the radiator & 80 & - \\
\hline $\begin{array}{l}\text { Hoses (two) associated with eliminated } \\
\text { components (pump and partitioned } \\
\text { radiator) }\end{array}$ & 28 & toyotapartscheap.com \\
\hline Total retail & 250 & \\
\hline Minus 25\% retail store profit & -62.5 & \\
\hline Wholesale & 187.50 & \\
\hline
\end{tabular}




\section{CONCLUSIONS}

This study consisted of a technical/engineering evaluation and literature search designed to investigate the feasibility of raising the coolant temperature of a Prius-like HEV system from $65^{\circ} \mathrm{C}$ to $105^{\circ} \mathrm{C}$. The study focused on subsystems and components that were deemed most vulnerable to operation at higher temperatures. These included the inverter power electronics, the dc-link capacitor for the inverter, and stator insulation and PMs in the PMSM.

There is high interest among the OEMs in reducing manufacturing cost to enhance their competitive standing. One candidate means of accomplishing this is by eliminating the HEV-dedicated coolant loop. In light of this "high interest," a positive "can-do" approach was used in this study to the fullest extent possible to fairly assess the potential or opportunity of relying entirely on a high-temperature coolant system. Nevertheless, it proved to be clearly evident that a few formidable technical and cost barriers exist and no effective approach for mitigating the barriers was identifiable in the near term.

The major barriers encountered in this study are:

1. Inverter dc link - High-temperature $\left(125^{\circ} \mathrm{C}\right.$ or higher $)$ capacitors with adequate ripple current and a $600 \mathrm{~V}$ continuous rating can be found today only by taking existing capacitors and using three in parallel or by using prohibitively expensive Teflon film capacitors. The first approach triples cost and size which is a serious penalty and a major barrier. There is a need for low-cost, high-temperature capacitors and it is important that these be brought to the market soon.

2. PMSM \#1 - The primary barrier for the PMSM is that the flux strength of the PMs will decrease $20-30 \%$ whenever the PMs are at elevated temperatures consistent with operation based on a high-temperature coolant. This will reduce PMSM/vehicle performance and/or require higher, compensating motor current. Higher motor current will compound the thermal control problem.

3. PMSM \#2 - Higher temperatures result in a very substantial $29 \%$ increase in losses due to temperature-induced changes in back-emf and stator winding copper losses. This will result in unacceptable temperatures for the stator insulation and PMs unless the cooling system is significantly improved and the size of the motor is increased to facilitate heat transfer. Detailed thermal studies will be required to produce a high-temperature motor design.

Although there were no "major barriers" for the inverter/converter power electronics, one issue remains. New 600V IGBTs, using a trench MOS-top-cell with ultra-thin $70-\mu \mathrm{m}$ wafer technology, may be qualified for $175^{\circ} \mathrm{C}$ junction temperature, but the maximum operating temperature under switching conditions is reduced to $150^{\circ} \mathrm{C}$. Because $150^{\circ} \mathrm{C}$ is much better than $125^{\circ} \mathrm{C}$ and most likely adequate, the thermal derating issue is mainly a design consideration.

The complete listings of design and cost barriers can be found at the end of the following sections:

Section 3.1.3 - Inverter/Converter Power-Electronic Devices

Section 3.2.4 - High-Temperature Capacitors

Section 3.3.4 - High-Temperature Motor Design

The system-level barrier study considers the cost savings of adopting a high-temperature coolant loop and then weighs that against the full range of costs/consequences resulting from necessary design changes. If 
the cost of resolving barriers exceeds the initial cost savings, clearly there is a serious system-level barrier. As indicated in Section 3.4, the wholesale cost savings of eliminating a dedicated cooling loop would be $\sim \$ 188$.

Table 4.1 lists the potential cost increases that would result from resolving the barriers for the major critical subsystems/components identified in this assessment. Other costs may be incurred for such things as inverter driver circuit improvements, the buck/boost converter high-temperature capacitor, improved oil spray design for stator cooling, etc. However, the costs of the items listed in Table 4.1 already exceed the $\$ 188$ cost savings of eliminating the dedicated coolant loop by a substantial amount. Even the summation of the minimum estimated costs exceeds the cost savings.

Table 4.1. Estimations of additional costs to resolve barriers in components/subsystems

\begin{tabular}{|l|l|c|}
\hline \multicolumn{1}{|c|}{$\begin{array}{c}\text { Subsystem or } \\
\text { Component }\end{array}$} & \multicolumn{1}{|c|}{ Constraints Specified by the Assessment } & $\begin{array}{c}\text { Estimates of } \\
\text { Additional Cost }\end{array}$ \\
\hline $\begin{array}{l}\text { Inverter power } \\
\text { electronics }\end{array}$ & $\begin{array}{l}\text { The future cost increase for high-temperature } \\
\text { power electronic modules when they become } \\
\text { available for full rated switching current with } \\
\text { minimal or no thermal derating. }\end{array}$ & $\begin{array}{c}\$ 25-125 / \text { inverter } \\
\$ 4-21 / \text { converter }\end{array}$ \\
\hline dc-link capacitors & $\begin{array}{l}\text { The cost increase of using 3X the capacitance } \\
\text { prior to new products becoming available } \\
\text { with adequate ripple current and a 600Vdc } \\
\text { continuous rating. }\end{array}$ & $\$ 210-250^{1}$ \\
\hline $\begin{array}{l}\text { PMSM (protecting PM } \\
\text { and stator insulation) }\end{array}$ & $\begin{array}{l}\text { The cost increase for additional casting in the } \\
\text { heat exchanger and other as-yet unknown } \\
\text { improvements necessary for control of PM } \\
\text { temperatures and dissipating higher losses. }\end{array}$ & $\$ 30-200$ \\
\hline \hline Total & & $\mathbf{\$ 2 6 9 - 5 9 6}$ \\
\hline
\end{tabular}

${ }^{1}$ This assumes the cost of a low-temperature capacitor, similar to that used in the Prius, is $\sim \$ 100$.

Table 4.2 is a qualitative comparison matrix of various parameters of interest for each of the critical components and subsystems. The parameters of interest include availability of components, mass, volume, performance, reliability, lifetime, and cost. For temperatures lower and higher than the $65^{\circ} \mathrm{C}$ base case, the potential thermal effect is designated as either being positive $(+)$ or negative $(-)$, where applicable. Major barriers are designated with double negatives. As an example using stator insulation, adopting a $105^{\circ} \mathrm{C}$ coolant would have negative impacts on mass, volume, and cost if it was necessary to use a different type of insulation, such as Class $\mathrm{C}$. This assessment considered remaining with Class $\mathrm{H}$ to be potentially feasible, depending on whether heat transfer can be significantly improved, in which case those negatives would not apply. This illustrates how some designations in the table are only potentially applicable. 
Table 4.2. Multi-parameter, temperature-based qualitative comparison

\begin{tabular}{|c|c|c|c|}
\hline Parameter & $50^{\circ} \mathrm{C}$ & $65^{\circ} \mathrm{C}$ & $105^{\circ} \mathrm{C}$ \\
\hline \multicolumn{4}{|c|}{ Elimination of HEV-Dedicated Cooling System } \\
\hline Cost & & Base case & + \\
\hline \multicolumn{4}{|c|}{ Inverter Power Electronics } \\
\hline Availability of components & & Base case & \\
\hline Mass & & Base case & \\
\hline Volume & & Base case & \\
\hline Vehicle performance & & Base case & \\
\hline Reliability & + & Base case & - \\
\hline Attaining a 15-year life & & Base case & - \\
\hline Cost & & Base case & \\
\hline \multicolumn{4}{|c|}{ dc-link Capacitor } \\
\hline Availability of components & & Base case & -- \\
\hline Mass & & Base case & - \\
\hline Volume & & Base case & - \\
\hline Vehicle performance & & Base case & \\
\hline Reliability & + & Base case & - \\
\hline Attaining a 15 -year life & + & Base case & - \\
\hline Cost & + & Base case & -- \\
\hline \multicolumn{4}{|c|}{ PMSM PMs } \\
\hline Availability of components & + & Base case & - \\
\hline Mass & & Base case & \\
\hline Volume & & Base case & \\
\hline Vehicle performance & + & Base case & -- \\
\hline Reliability & + & Base case & - \\
\hline Attaining a 15-year life & + & Base case & - \\
\hline Lack of a new PMSM design $^{1}$ & & Base case & -- \\
\hline Cost & + & Base case & - \\
\hline \multicolumn{4}{|c|}{ PMSM Stator Insulation } \\
\hline Availability of components & & Base case & \\
\hline Mass & & Base case & - \\
\hline Volume & & Base case & - \\
\hline Vehicle performance & & Base case & - \\
\hline Reliability & & Base case & \\
\hline Attaining a 15-year life & & Base case & - \\
\hline Lack of a new PMSM design $^{1}$ & & Base case & -- \\
\hline Cost & & Base case & - \\
\hline
\end{tabular}

${ }^{1}$ A new design is needed for significantly improved heat dissipation. 


\section{APPENDIX A \\ CALCULATIONS OF INVERTER LOSSES VS. TEMPERATURE}

This appendix evaluates the losses of high-temperature IGBTs and diodes based on information contained in the manufacturer's specifications literature for the devices. Concerns pertaining to thermal derating based on switching current is not addressed in this appendix but is discussed in Section 3.

\section{A.1 CONDUCTION LOSSES IN IGBTS [24,25]}

IGBTs have a positive temperature coefficient at and above rated current. A positive temperature coefficient indicates that the resistance of the IGBT will increase with temperature. Therefore, an increase in temperature will result in higher losses.

For this analysis an Infineon TrenchStop IGBT (IGW75N60T) is examined. This IGBT has a maximum rated junction temperature of $175^{\circ} \mathrm{C}$ and a maximum forward current of $150 \mathrm{~A}$. Using the data provided by the manufacturer, several calculations are presented to depict the effects of temperature on packaging, power losses, and efficiency.

First, values of the voltage and current in respect to temperature were obtained through interpolation of the data from the manufacturer. Using this data, a comparison of the power dissipated across the device vs. temperature in respect to current is provided in Fig. A.1 for two different currents. From this graph, it is evident that as temperature increases there is an increase in the amount of power dissipated in the device, especially at high current levels.

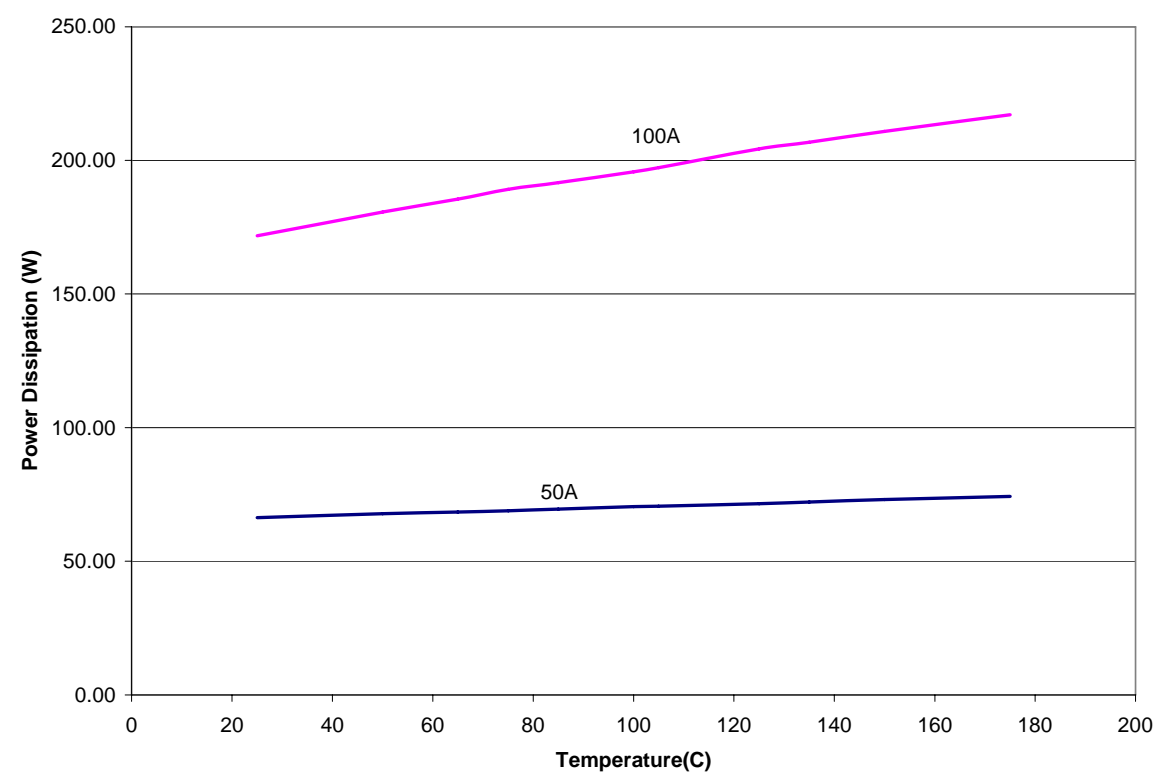

Fig. A.1. IGBT dissipated power vs. temperature in respect to current.

For comparison purposes, the assumption is made that an IGBT junction-to-ambient temperature of $70^{\circ} \mathrm{C}$ is maintained independent of the type of cooling. For this study, the cooling is based on $65^{\circ} \mathrm{C}$ and $105^{\circ} \mathrm{C}$ 
ambient temperatures or $135^{\circ} \mathrm{C}^{3}$ and $175^{\circ} \mathrm{C}$ junction temperatures, respectively. From Fig. A.1, the conduction losses at these different temperatures were interpolated and recorded in Table A.1.

Table A.1. Temperature-dependent conduction losses in an IGBT

\begin{tabular}{|c|c|c|c|c|}
\hline \multirow{2}{*}{$\begin{array}{c}\text { Temperature } \\
\left({ }^{\circ} \mathbf{C}\right)\end{array}$} & \multicolumn{2}{|c|}{$\mathbf{5 0}$ amps } & \multicolumn{2}{c|}{ 100 amps } \\
\cline { 2 - 5 } & Voltage Drop (V) & Loss (W) & Voltage Drop (V) & Loss (W) \\
\hline 65 & 1.37 & 68.4 & 1.85 & 185.5 \\
\hline 105 & 1.41 & 70.6 & 1.97 & 197.3 \\
\hline 135 & 1.44 & 72.2 & 2.07 & 206.8 \\
\hline 175 & 1.49 & 74.3 & 2.17 & 217.2 \\
\hline
\end{tabular}

Note that at $50 \mathrm{~A}$ there is an increase in power dissipated across the device of only $2.1 \mathrm{~W}$ when going from $135-175^{\circ} \mathrm{C}$ junction temperatures and at $100 \mathrm{~A}$ this increase becomes $10.4 \mathrm{~W}$. Therefore at $50 \mathrm{~A}$ and $100 \mathrm{~A}$, the losses increase by $2.9 \%$ and $5.0 \%$, respectively, when increasing the coolant temperature from $65-105^{\circ} \mathrm{C}$.

Although this gives an indication of the efficiency, limitations on the size of the device based on an increase in temperature should still be investigated. However, sizing of the device is mostly based on the packaging constraints. Depending on the type of package, many different size adjustments can be made. Therefore, the thermal resistance necessitated by the device will be calculated to provide an indication of the type of packaging. The thermal model shown in Fig. A.2 can be used to determine the packaging requirements of the IGBT where $T_{j}$ is the junction temperature, $T_{a}$ is the ambient temperature, $R_{j a}$ is the thermal resistance of the IGBT packaging and heat sink, and $\mathrm{P}$ is the power dissipated across the device.

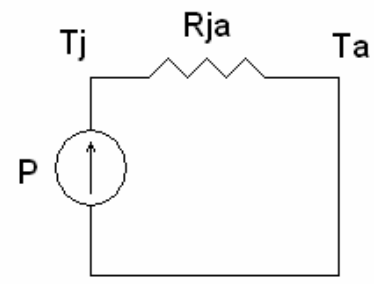

Fig. A.2. Thermal resistance model of an IGBT.

$$
\begin{aligned}
\mathrm{R}_{\mathrm{ja}} & =\frac{\mathrm{T}_{\mathrm{j}}-\mathrm{T}_{\mathrm{a}}}{\mathrm{P}_{\text {DISP }}}=\frac{135^{\circ} \mathrm{C}-65^{\circ} \mathrm{C}}{72.2 \mathrm{~W}}=0.970 \frac{{ }^{\mathrm{o}} \mathrm{C}}{\mathrm{W}} \\
\mathrm{R}_{\mathrm{ja}}= & \frac{\mathrm{T}_{\mathrm{j}}-\mathrm{T}_{\mathrm{a}}}{\mathrm{P}_{\text {DISP }}}=\frac{175^{\circ} \mathrm{C}-105^{\circ} \mathrm{C}}{74.3 \mathrm{~W}}=0.942 \frac{{ }^{\mathrm{o}} \mathrm{C}}{\mathrm{W}}
\end{aligned}
$$

The calculations show that with $105^{\circ} \mathrm{C}$ coolant, a thermal resistance of $0.942^{\circ} \mathrm{C} / \mathrm{W}$ is necessitated for adequate cooling while, with a $65^{\circ} \mathrm{C}$ coolant, $0.970^{\circ} \mathrm{C} / \mathrm{W}$ is sufficient. This seems to suggest that if the same packaging is used on both designs the $105^{\circ} \mathrm{C}$ package would need to be 1.03 times larger.

\footnotetext{
${ }^{3}$ The $135^{\circ} \mathrm{C}$ junction temperature reflects a smaller design margin than the $125^{\circ} \mathrm{C}$ temperature used in Section 3. It is still an acceptable temperature given that the maximum junction temperature is $150^{\circ} \mathrm{C}$.
} 


\section{A.2 SWITCHING LOSSES IN IGBTS}

The manufacturer provides data relating to switching energy and temperature at a rated current of $75 \mathrm{~A}$ as seen in Fig. A.3. As evident in the top plot in the graph, the switching energy increases with temperature.

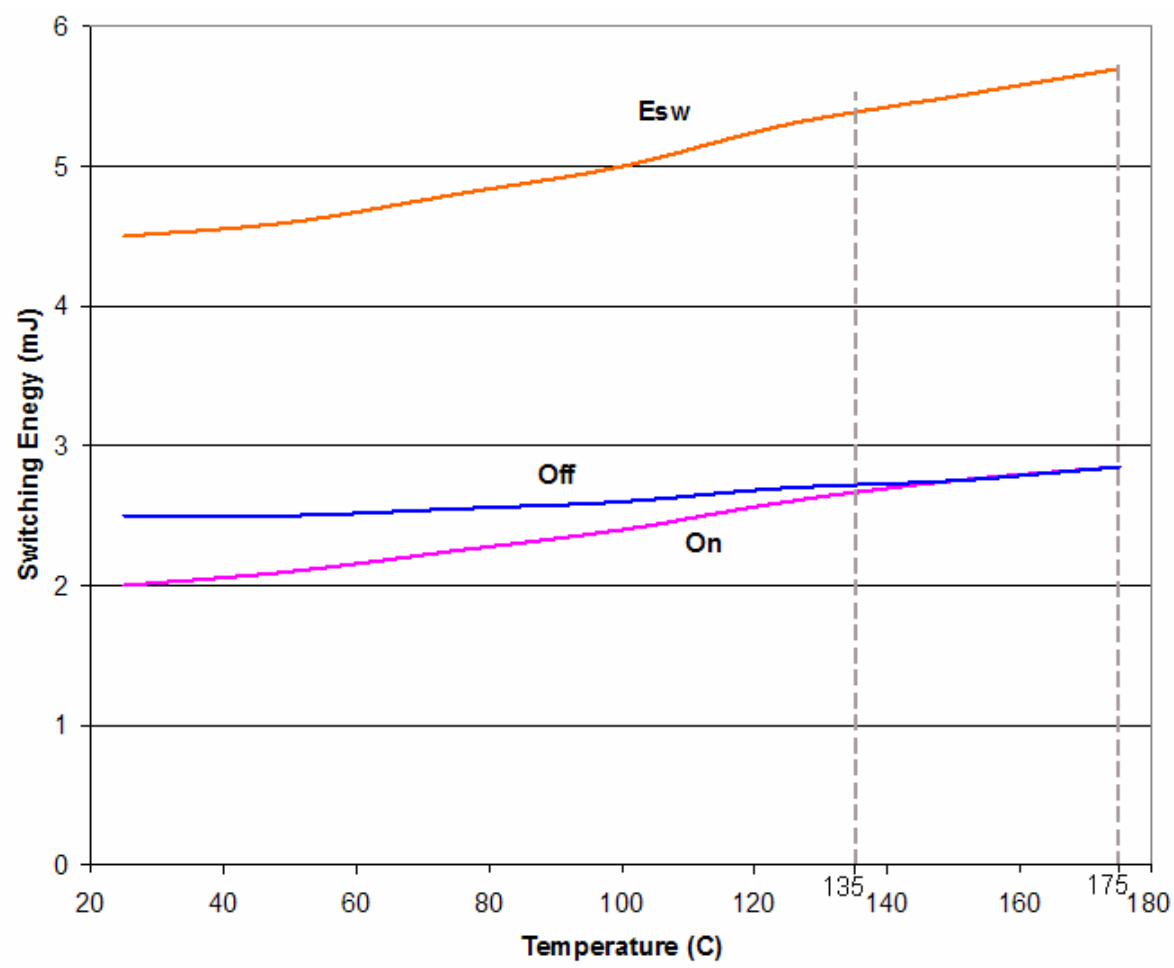

Fig. A.3. IGBT switching energy vs. temperature at maximum rated current (75A).

To obtain the power dissipated across the device due to switching, the switching energy can be multiplied by the frequency as seen by the following equation [26]

$$
P_{s w}=E_{s w} * f_{s} .
$$

Figure A.4 shows the relationship of switching power in terms of terms of temperature and frequency. As apparent from the graph, as the switching frequency increases, the effect of temperature also appears to increase as the curve becomes less linear. 


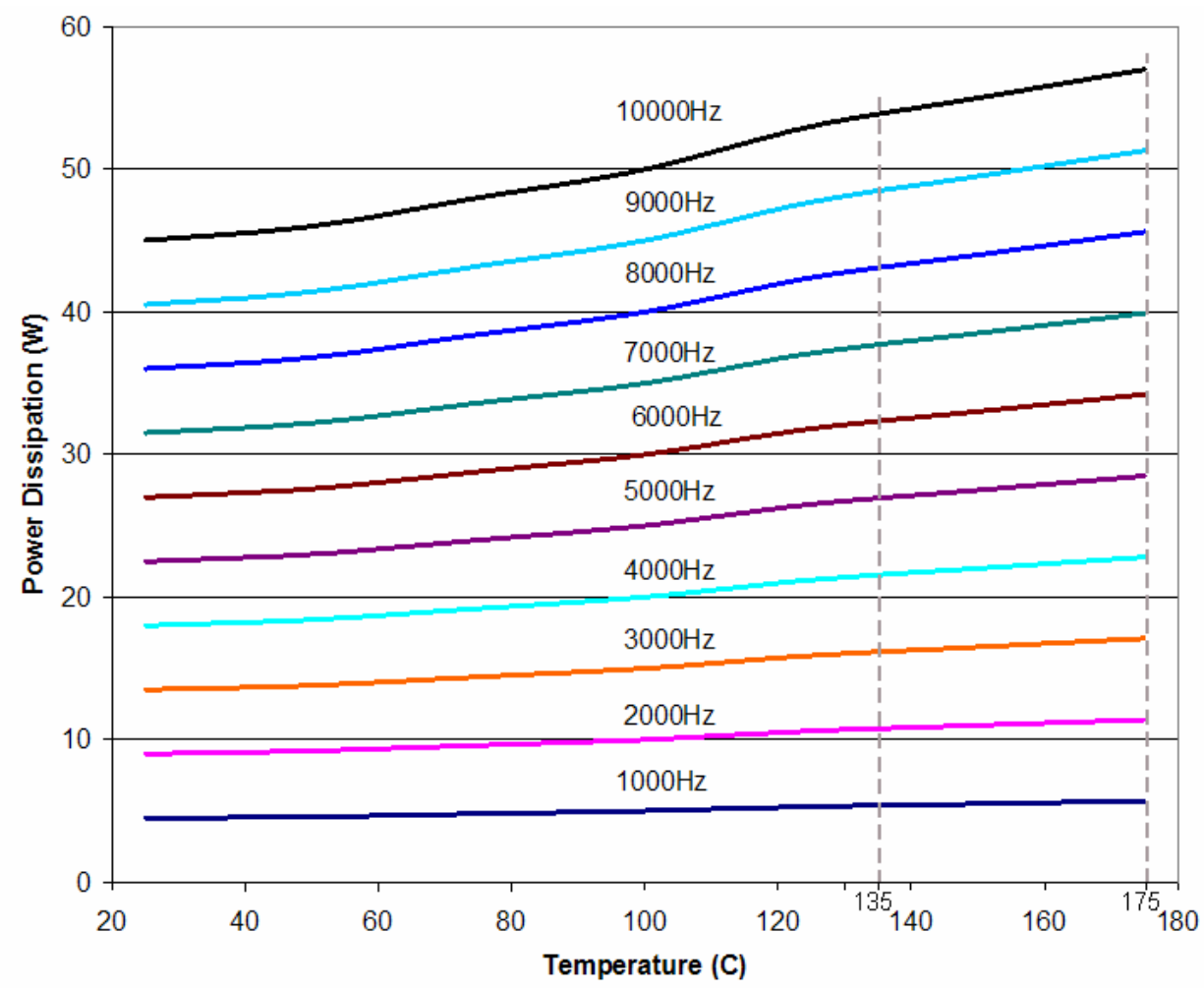

Fig. A.4. IGBT switching power vs. temperature in respect to frequency.

\section{A.3 CONDUCTION LOSSES IN DIODES}

Unlike IGBTs, diodes have a negative temperature coefficient at or below rated current. Therefore, when temperature increases, the resistance decreases and leads to lower losses.

For this analysis, an Infineon fast switching diode (IDW75E60) is considered. This diode has a maximum rated junction temperature of $175^{\circ} \mathrm{C}$ and a maximum forward current of $120 \mathrm{~A}$. Using the data provided by the manufacturer, several calculations are presented to help depict the effects of temperature on efficiency and packaging.

The same approach is used as in the calculation of conduction losses for the IGBTs for a temperature difference of $70^{\circ} \mathrm{C}$ between the junction and ambient. The losses due to an increase in temperature at 50A and 100A are determined and recorded in Table A.2. Since the values of current chosen are in close proximity to the cross-over point, temperature has little effect on the losses. As temperature is increased (from $135-175^{\circ} \mathrm{C}$ ), the losses at $50 \mathrm{~A}$ and $100 \mathrm{~A}$ decrease by $2.3 \%$ and $1.3 \%$, respectively.

Table A.2. Conduction losses in an IDW75E60 power diode

\begin{tabular}{|c|c|c|c|c|}
\hline \multirow{2}{*}{$\begin{array}{c}\text { Interpolated } \\
\text { Temperature } \\
\text { Data }\left({ }^{\circ} \mathrm{C}\right)\end{array}$} & \multicolumn{2}{|c|}{50 amps } & \multicolumn{2}{|c|}{100 amps } \\
\hline & $\begin{array}{c}\text { Voltage Drop } \\
\text { (V) }\end{array}$ & Loss (W) & $\begin{array}{c}\text { Voltage Drop } \\
\text { (V) }\end{array}$ & Loss (W) \\
\hline 65 & 1.44 & 72.1 & 1.88 & 189.9 \\
\hline 105 & 1.41 & 70.7 & 1.89 & 188.7 \\
\hline 135 & 1.41 & 70.4 & 1.91 & 191.3 \\
\hline 175 & 1.38 & 68.8 & 1.89 & 188.9 \\
\hline
\end{tabular}




\section{A.4 POWER DISSIPATION OF POWER ELECTRONIC DEVICES}

The inverter converts the dc power supplied by the battery pack to ac power through the use of switches. By switching at the appropriate intervals, usually through the use of PWM, an ac waveform can be achieved. The switches are actually a combination of IGBTs and diodes placed in parallel. Figure A.5 shows a typical three phase inverter. As is evident, six switches/IGBTs and six diodes are necessary for the three-phase inverter to function.

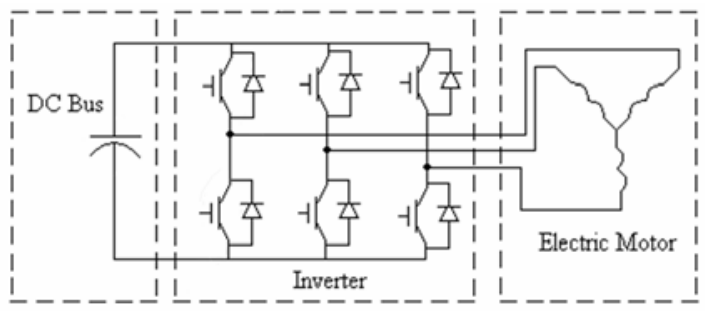

Fig. A.5. Standard inverter diagram with six switches and six diodes.

To determine the power losses across an inverter, switching losses and conduction losses must be taken into account. The following equation relates the total power dissipated with the switching power and conduction losses

$$
P_{\text {Disp }}=P_{\text {switching }}+P_{\text {conduction }}
$$

The switching losses are straightforward, and were determined in the previous section. The conduction losses on the other hand are not as simple. Conduction does not occur during the entire period and depending on the modulation scheme can be different. For PWM switching, the following equations are provided for the conduction loss $[24,25]$

$$
P_{C O N D}=I^{2} * R_{D} *\left(\frac{1}{8}+\frac{1}{3 \pi} M * \cos \phi\right)+I^{*} V_{D} *\left(\frac{1}{2 \pi}+\frac{1}{8} M * \cos \phi\right)
$$

and

$$
P_{\mathrm{COND}}=I^{2} * R_{D} *\left(\frac{1}{8}-\frac{1}{3 \pi} M * \cos \phi\right)+I^{*} V_{D} *\left(\frac{1}{2 \pi}-\frac{1}{8} M * \cos \phi\right) \quad \text { (DIODE). }
$$

where $I$ is the peak current, $R_{D}$ is on the state resistance, $M$ is the modulation index, $\cos \phi$ is the power factor, and $V_{D}$ is the on-state voltage drop. Data was generated to reflect inverter operation at full modulation $(\mathrm{M}=1)$ and at a power factor of 0.98 . Table A.3 provides full inverter diode losses (six diode pairs) vs. temperature based on the conduction equation for three different inverter peak currents of 100A, 150A, and 200A. Similarly, Table A.4 provides full inverter IGBT conduction and switching losses (based on 12 IGBTs). Table A.5 provides the summation of the total losses based on the estimates in the previous two tables. Table A.5 shows that, when going from junction temperatures of $135-175^{\circ} \mathrm{C}$, the total losses increase by $3.7 \%, 4.2 \%$, and $4.7 \%$ for the $100 \mathrm{~A}, 150 \mathrm{~A}$, and $200 \mathrm{~A}$ cases, respectively. 
Table A.3. Full bridge inverter diode losses using the conduction loss equation

\begin{tabular}{|c|c|c|c|c|c|}
\hline \multirow{2}{*}{$\begin{array}{c}\text { Junction } \\
\text { Temperature } \\
\left({ }^{\circ} \mathbf{C}\right)\end{array}$} & $\begin{array}{c}\text { On-State } \\
\text { Voltage } \\
\text { Drop i = } \\
\mathbf{A ~ ( V d ) ~}\end{array}$ & $\begin{array}{c}\text { Resistance } \\
\text { (mOhms) }\end{array}$ & $\mathbf{1 0 0 A}$ & $\mathbf{1 5 0 A}$ & $\mathbf{2 0 0 A}$ \\
\cline { 4 - 6 } & 1.03 & 0.00812 & 27.8 & 45.5 & 65.8 \\
\hline 50 & 0.99 & 0.00933 & 27.7 & 45.9 & 67.1 \\
\hline 75 & 0.95 & 0.01034 & 27.4 & 46.0 & 67.9 \\
\hline 100 & 0.90 & 0.00996 & 26.2 & 44.0 & 65.0 \\
\hline 125 & 0.90 & 0.01011 & 26.2 & 44.1 & 65.2 \\
\hline 135 & 0.90 & 0.01034 & 26.3 & 44.3 & 65.6 \\
\hline 150 & 0.86 & 0.01023 & 25.5 & 43.1 & 63.9 \\
\hline 175 & & & & & \\
\hline
\end{tabular}

Table A.4. IGBT conduction and switching losses in a full bridge inverter

\begin{tabular}{|c|c|c|c|c|c|c|c|c|}
\hline \multirow{2}{*}{$\begin{array}{c}\text { Junction } \\
\text { Temperature } \\
\left({ }^{\circ} \mathrm{C}\right)\end{array}$} & \multirow{2}{*}{$\begin{array}{c}\text { On-State } \\
\text { Voltage } \\
\text { Drop i = 0A } \\
\text { (Vd) }\end{array}$} & \multirow{2}{*}{$\begin{array}{l}\text { Resistance } \\
\text { (mOhms) }\end{array}$} & \multicolumn{3}{|c|}{$\begin{array}{c}\text { Conduction Losses } \\
\text { (W) }\end{array}$} & \multicolumn{3}{|c|}{$\begin{array}{c}\text { Switching Losses } \\
(\mathrm{W})\end{array}$} \\
\hline & & & $100 A$ & $150 \mathrm{~A}$ & $200 A$ & $100 \mathrm{~A}$ & $150 \mathrm{~A}$ & 200A \\
\hline 50 & 0.904 & 0.0090 & 213 & 366 & 550 & 184 & 276 & 414 \\
\hline 75 & 0.865 & 0.0103 & 215 & 376 & 571 & 192 & 288 & 433 \\
\hline 100 & 0.859 & 0.0110 & 219 & 385 & 589 & 200 & 300 & 451 \\
\hline 125 & 0.820 & 0.0122 & 221 & 395 & 610 & 212 & 318 & 479 \\
\hline 135 & 0.818 & 0.0125 & 223 & 398 & 617 & 215 & 323 & 487 \\
\hline 150 & 0.815 & 0.0129 & 225 & 404 & 628 & 220 & 330 & 498 \\
\hline 175 & 0.799 & 0.0137 & 228 & 413 & 644 & 228 & 342 & 516 \\
\hline
\end{tabular}

Table A.5. Total inverter losses (IGBT and diode losses)

\begin{tabular}{|c|c|c|c|}
\hline \multirow{2}{*}{$\begin{array}{c}\text { Junction } \\
\text { Temperature } \\
\left({ }^{\circ} \mathbf{C}\right)\end{array}$} & \multicolumn{3}{|c|}{ Total Losses (W) } \\
\cline { 2 - 4 } & $\mathbf{1 0 0 A}$ & $\mathbf{1 5 0 A}$ & $\mathbf{2 0 0 A}$ \\
\hline 50 & 425 & 688 & 1030 \\
\hline 75 & 435 & 709 & 1071 \\
\hline 100 & 447 & 731 & 1108 \\
\hline 125 & 459 & 757 & 1154 \\
\hline 135 & 464 & 765 & 1169 \\
\hline 150 & 471 & 779 & 1191 \\
\hline 175 & 481 & 798 & 1224 \\
\hline
\end{tabular}

The data presented in Table A.6 show the relationship between efficiency and temperature based on the combined IGBT and diode thermal dissipation losses relative to an inverter with a $55 \mathrm{~kW}$ peak power rating. It is very pertinent to this study to note that when comparing the efficiencies at $135^{\circ} \mathrm{C}$ and $175^{\circ} \mathrm{C}$, the differences are quite small $(0.01 \%, 0.06 \%$, and $0.1 \%$ for the $100 \mathrm{~A}, 150 \mathrm{~A}$, and $200 \mathrm{~A}$ cases, respectively). 
Table A.6. Switching and total inverter efficiency

\begin{tabular}{|c|c|c|c|}
\hline $\begin{array}{c}\text { Junction Temp } \\
\left({ }^{\circ} \mathbf{C}\right)\end{array}$ & $\mathbf{1 0 0 A}$ & $\mathbf{1 5 0 A}$ & $\mathbf{2 0 0 A}$ \\
\hline 50 & $99.23 \%$ & $98.75 \%$ & $98.13 \%$ \\
\hline 75 & $99.21 \%$ & $98.71 \%$ & $98.05 \%$ \\
\hline 100 & $99.19 \%$ & $98.67 \%$ & $97.98 \%$ \\
\hline 125 & $99.16 \%$ & $98.62 \%$ & $97.90 \%$ \\
\hline 135 & $99.16 \%$ & $98.61 \%$ & $97.87 \%$ \\
\hline 150 & $99.14 \%$ & $98.58 \%$ & $97.83 \%$ \\
\hline 175 & $99.12 \%$ & $98.55 \%$ & $97.77 \%$ \\
\hline
\end{tabular}

Table A.7 contains calculations for the thermal resistance at 100A, 150A, and 200A levels. The change in thermal resistance between the two temperatures is large enough that the effect on heat transfer may have to be accounted for in the inverter design.

Table A.7. Switching and total inverter losses

\begin{tabular}{|c|c|c|c|}
\hline \multirow{2}{*}{ Current Rating } & \multicolumn{2}{|c|}{ Thermal Resistance } & \multirow{2}{*}{$\%$ Change } \\
\cline { 2 - 3 } & $\mathbf{1 3 5}^{\circ} \mathbf{C}$ & $\mathbf{1 7 5}^{\circ} \mathbf{C}$ & \\
\hline $100 \mathrm{~A}$ & 1.92 & 1.84 & $4.2 \%$ \\
\hline $150 \mathrm{~A}$ & 1.16 & 1.11 & $4.3 \%$ \\
\hline $200 \mathrm{~A}$ & 0.76 & 0.72 & $5.3 \%$ \\
\hline
\end{tabular}




\section{APPENDIX B \\ ANALYTICAL ASSESSMENT OF A PMSM CIRCUIT [14, 27-28]}

This appendix will look at the motor circuit-level effects of temperature on magnets and magnetic flux. Once the temperature-induced effects on back-emf and stator resistance are characterized, they will be combined mathematically to determine the elevated temperature-induced decreases in motor electrical power and efficiency.

This theoretical assessment, based on magnetic properties and copper resistance, is a limited electric circuit analysis and does not fully describe the complete electromechanical system of the PMSM. The full assessment of the PMSM is completed using the thermal test data presented in Section 3.3.

For the PMSM, temperature plays two significant roles. First, the residual flux density is affected with increase in temperature. This reduction in flux from increased temperature results in a lower back-emf given by.

$$
E=E_{A}\left(1+\frac{s\left(T-T_{A}\right)}{B_{r A}}\right)
$$

where $T_{A}$ is the ambient temperature, $E_{A}$ is the back-emf at $T_{A}, s$ is the slope of the flux curve, and $B_{r A}$ is the flux at ambient temperature. The back-emf of a motor with the parameters given in Table B.1 has the back-emf vs. temperature plot shown in Fig. B.1.

Table B.1. Example motor for back-emf analysis

\begin{tabular}{|l|c|}
\hline \multicolumn{1}{|c|}{ Motor Parameter } & Value \\
\hline$B$, Tesla & 1.12 \\
\hline Rated Power, $\mathrm{kW}$ & 30 \\
\hline Back-emf at base speed, V & 120 \\
\hline Stator resistance, ohms & 0.0174 \\
\hline Operation speed & Base speed \\
\hline
\end{tabular}

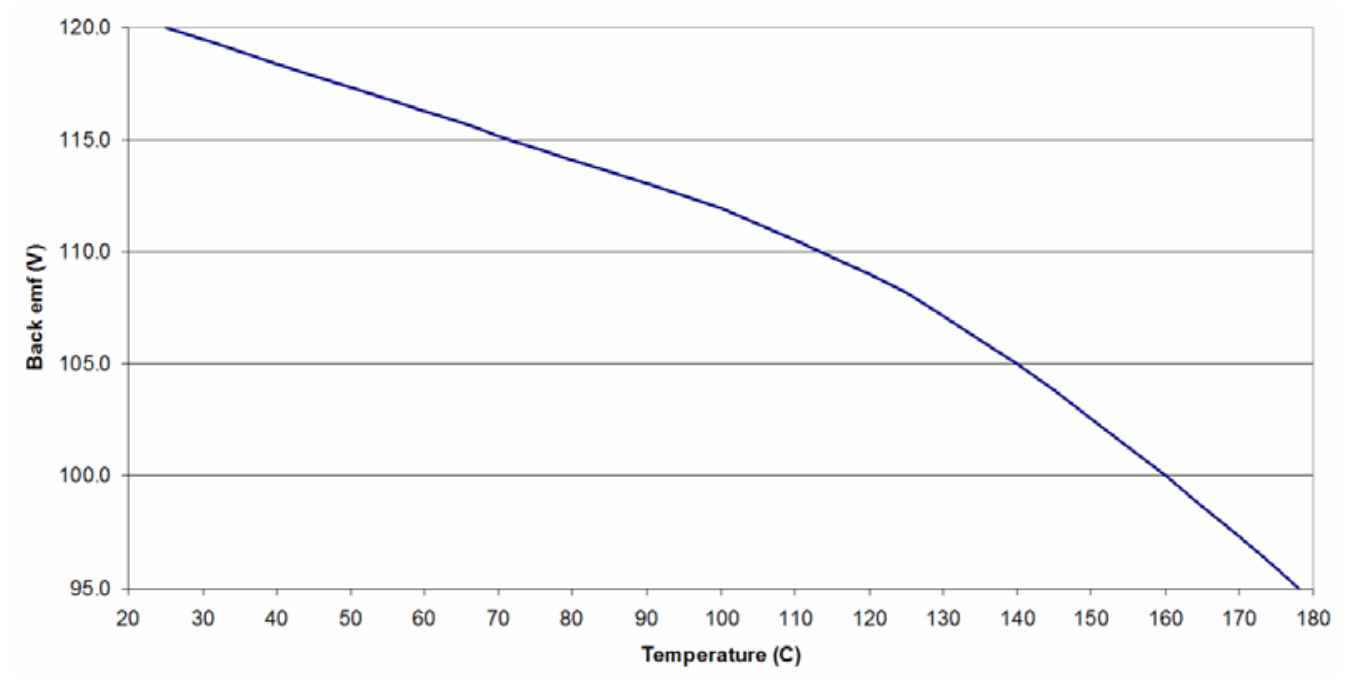

Fig. B.1. Example of PMSM back-emf vs. PMSM temperature. 
The second effect of temperature on a PMSM is an increase in the stator copper resistance as noted by the following equation

$$
R=R_{A}\left(1+\alpha\left(T-T_{A}\right)\right)
$$

where $R_{A}$ is the resistance at ambient temperature, $T_{A}$, and $\alpha$ is the coefficient of resistance for copper which is $3.35 \times 10^{-3}$.

Using the example parameters, Fig. B.2 provides a view of the stator resistance vs. increasing temperature. In making a $40^{\circ} \mathrm{C}$ increase in temperature, consistent with the change in coolant temperature, the stator resistance increases by $10 \%$.

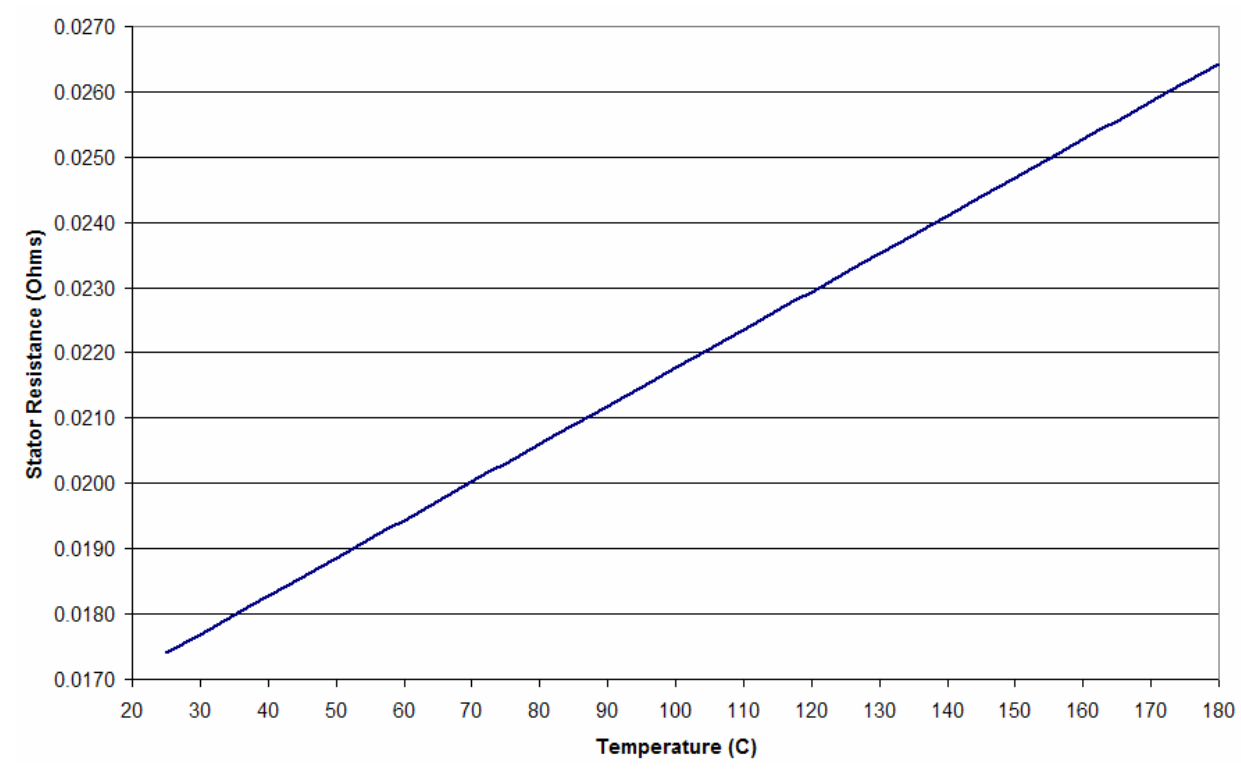

Fig. B.2. Stator copper resistance vs. temperature.

Now that the temperature effects on motor back-emf and stator resistance have been derived, the results will be used to determine the combined effect on motor power and efficiency. For PMSMs, Fig. B.3 shows a general circuit model used to calculate needed parameters where Vs is the ac voltage supplied by an inverter, $\mathrm{R}$ is the stator winding resistance and $\mathrm{E}$ is the back-emf.

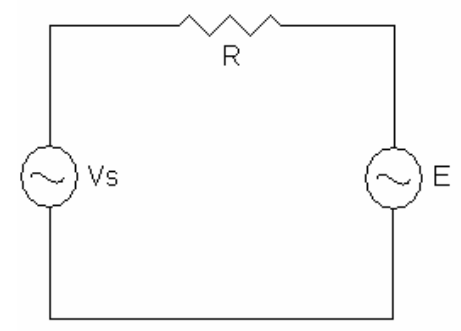

Fig. B.3. Basic motor circuit model. 
Using the circuit model, several equations can be derived to relate efficiency to the temperature of a PMSM. First, the current is given by

$$
I=\frac{V S-E}{R}=\frac{V s-E_{A}\left(1+\frac{\Delta T}{B}\right)}{R_{A}(1+\alpha \Delta T)} .
$$

The equation for the input power is provided by

$$
\operatorname{Pin}=I^{*} V_{S}=\frac{V_{S}-E_{A}\left(1+\frac{\Delta T}{B}\right)}{R_{A}(1+\alpha \Delta T)} * V_{S} .
$$

Holding the input power constant and solving for the input voltage, $V_{S}$, yields the polynomial

$$
V s^{2}-E_{A}\left(1+\frac{\Delta T}{B}\right) V s-\operatorname{Pin}^{*} R_{A}(1+\alpha \Delta T)=0
$$

or

$$
\mathrm{Vs}=\frac{\mathrm{E}_{\mathrm{A}}\left(1+\frac{\Delta \mathrm{T}}{\mathrm{B}}\right)+\sqrt{\left(\mathrm{E}_{\mathrm{A}}\left(1+\frac{\Delta \mathrm{T}}{\mathrm{B}}\right)\right)^{2}+\operatorname{Pin} * \mathrm{R}_{\mathrm{A}}(1+\alpha \Delta \mathrm{T})}}{2} .
$$

With $V_{S}$, the current can be calculated. Using the current value and the following equation, the output power can be calculated in terms of temperature

$$
\text { Pout }=I * E=\frac{V s-E_{A}\left(1+\frac{\Delta T}{B}\right)}{R_{A}(1+\alpha \Delta T)} * E_{A}\left(1+\frac{\Delta T}{B}\right) .
$$

Finally the efficiency of the PM motor can be determined by

$$
\eta=\frac{\text { Pin }}{\text { Pout }}
$$

Based on the results of the PMSM circuit model analysis, the motor efficiency vs. temperature plot is shown in Fig. B.4. The right-hand portion of the plot shows that a PMSM whose temperature is raised from $65^{\circ} \mathrm{C}$ to $105^{\circ} \mathrm{C}$ will suffer a $1.6 \%$ loss in efficiency or a very significant $29 \%$ increase in losses. This is based on temperatures of $170^{\circ} \mathrm{C}$ and $130^{\circ} \mathrm{C}$ to reflect example stator temperatures that are considerably higher than the coolant temperatures. This places the motor operation at two temperature points in a steep portion of the curve. If the temperature increases still further, the increase in losses may easily approach $40 \%$. 


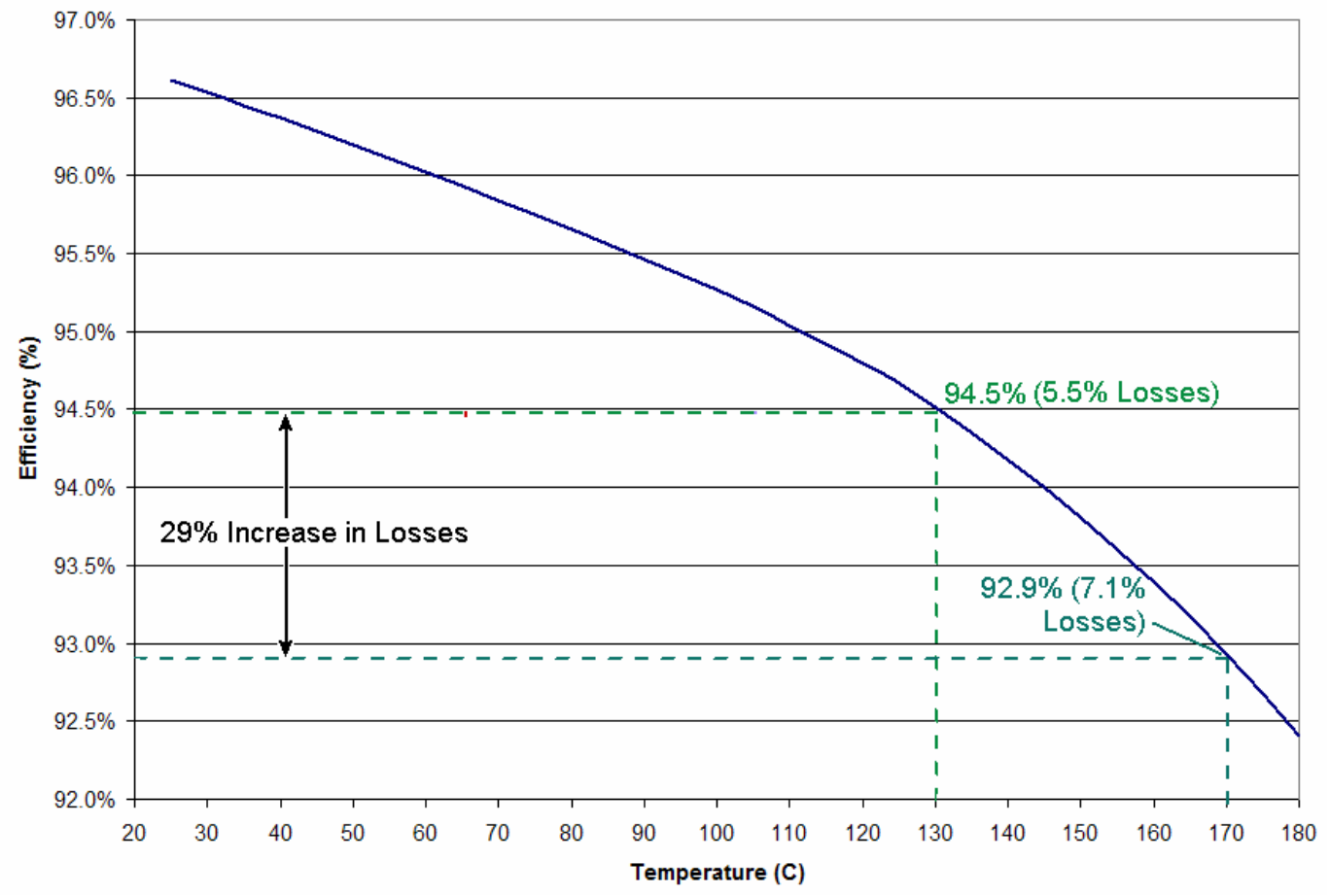

Fig. B.4. PMSM circuit model predicted efficiency vs. temperature. 


\section{REFERENCES}

1. J. S. Hsu, S. C. Nelson, et al, Report on Toyota Prius Motor Thermal Management, ORNL/TM-2005/33, UT-Battelle, LLC, Oak Ridge National Laboratory, Oak Ridge, Tennessee, February 2005.

2. R. H. Staunton, C. W. Ayers, J. Chiasson, T. A. Burress, and L. D. Marlino, Evaluation of 2004 Toyota Prius Hybrid Electric Drive System, ORNL/TM-2006-423, UT-Battelle, LLC, Oak Ridge National Laboratory, Oak Ridge, Tennessee, May 16, 2006.

3. Correspondence from S. A. Tarnowsky (General Motors/Saturn) to R. H. Staunton (ORNL), ORNL Green Line Motor and Inverter Info Request and Response, May 2006.

4. P. Kanschat, H. Ruthing, et al, "600V-IGBT: A Detailed Analysis of Outstanding Static and Dynamic Properties," PCIM Europe Conference 2004.

5. Communication from J. Mookken (Semikron) to R. H. Staunton (ORNL) via email, Inverters for High Temperature, and phone on August 7, 2006.

6. T. I. Bajenescu and M. I. Bazu, "Reliability of Electronic Components" Springer-Verlag, Heidelberg, Berlin, 1999.

7. http://www.illinoiscapacitor.com/techcenter/lifecalculators.asp, Illinois Capacitor.

8. http://www.filmcapacitors.com/dielect.htm\#props, Electronic Film Capacitors, Inc., 2000.

9. J. Prymak, Ripple Current Capabilities, 2004 KEMET Technical Update, KEMET Corporation, December 2004.

10. J. Mookken, Semikron, High Temperature $\left(105^{\circ} \mathrm{C}\right)$ Inverter Development, presentation at DOE FreedomCAR Vehicle Technology Program Annual Review, Oak Ridge, Tennessee, August 2006

11. http://www.mceproducts.com/knowledge-base/article/article-dtl.asp?id=32, Magnetic Component Engineering.

12. http://www.armsmag.com/samarium cobalt_magnet.htm, Armstrong Magnetics Inc.

13. Arnold Technologies, "TechNotes: How to Select the Appropriate Permanent Magnet Material," December 2002.

14. R. H. Staunton, S. C. Nelson, P. J. Otaduy, et al, PM Motor Parametric Design Analyses for a Hybrid Electric Vehicle Traction Drive Application, ORNL/TM-2004/217, UT-Battelle, LLC, Oak Ridge National Laboratory, Oak Ridge, Tennessee, September 2004

15. Anil Naji, "High Performance Permanent Magnets 7," Catalog, Magnet Sales and Manufacturing Inc., 1995.

16. S. J. Collocott, J. B. Dunlop, P. B. Gwan, B.A. Kalan, H.C. Lovatt, and W. Wu, "Applications of Rare-Earth Permanent Magnets in Electrical Machines: From Motors for Niche Applications to Hybrid Electric Vehicles," pp. 77-83 in Material Science Forum, 315, 1999.

17. J. F Gieras and M. Wing "Permanent Magnet Motor Technology."

18. J. G. West, "Propulsion Systems for Hybrid Electric Vehicles."

19. UQM Annual Report, 2005.

20. T. Sebastion "Temperature Effects on Torque Production and Efficiency of PM Motors Using NdFeB Magnets," IEEE Transactions on Industrial Applications, 31(2), April 1995.

21. F. Crescimbini, A. D. Napoli, L. Solero, and F. Caricchi, "Compact Permanent-Magnet Generator for Hybrid Vehicle Applications," IEEE Transactions on Industrial Applications, 41(5), October 2005.

22. Akira Kawahashi, "A New Generation Hybrid Electric Vehicle and Its Supporting Power Semiconductor Devices," Proceedings of 2004 International Symposium on Power Semiconductor Devices and ICs, Toyota Motor Corporation, 2004.

23. Verbal communication from Dr. Hitoshi Yamamoto of Neomax America, Inc. to J. S. Hsu (ORNL) during the 2005 Permanent Magnet Conference, 2005.

24. F. Casanellas, "Losses in PWM Inverters Using IGBTs" pp. 235-239 in Electric Power Applications, IEE Proceedings, 141(5), September 1994. 
25. L.K. Mestha and P.D. Evans, "Analysis of On-state Losses in PWM Inverters" pp. 189-195 in Electric Power Applications, IEE Proceedings, 136(4), July 1989.

26. N. Mohan, T. M. Undlenad, and W. P. Robbins, Power Electronics: Converters, Applications, and Design, John Wiley \& Sons Inc, New York, 1989.

27. Z. J. Liu, D. Howe, P. H. Mellor, and M. K. Jenkins, "Coupled Thermal and Electromagnetic Analysis of a Permanent Magnet Brushless DC Servo Motor," Electric Machines and Drives Conference, Sixth International Version, September 1993.

28. M. Ehsani, Y. Gao, S. E. Gay, and A. Emadi, Modern Electric, Hybrid Electric, and Fuel Cell Vehicles, CRC Press, 2005. 


\title{
DISTRIBUTION
}

Internal

\author{
1. D. J. Adams \\ 2. K. P. Gambrell \\ 3. J. S. Hsu \\ 4. E. C. Fox \\ 5. L. D. Marlino
}

6. M. Olszewski

7. M. R. Starke

8. R. H. Staunton

9. Laboratory Records

\section{External}

10. R. Al-Attar, DCX, raa9@dcx.com.

11. T. Q. Duong, U.S. Department of Energy, EE-2G/Forrestal Building, 1000 Independence Avenue, S.W., Washington, D.C. 20585.

12. R. R. Fessler, BIZTEK Consulting, Inc., 820 Roslyn Place, Evanston, Illinois 60201-1724.

13. K. Fiegenschuh, Ford Motor Company, Scientific Research Laboratory, 2101 Village Road, MD2247, Dearborn, Michigan 48121.

14. V. Garg, Ford Motor Company, 15050 Commerce Drive, North, Dearborn, Michigan 481201261.

15. G. Hagey, Sentech, Inc., 501 Randolph St., Williamsburg, Virginia 23185.

16. E. Jih, Ford Motor Company, Scientific Research Laboratory, 2101 Village Road, MD-1170, Rm. 2331, Dearborn, Michigan 48121.

17. A. Lee, Daimler Chrysler, CIMS 484-08-06, 800 Chrysler Drive, Auburn Hills, Michigan 483262757.

18. F. Liang, Ford Motor Company, Scientific Research Laboratory, 2101 Village Road, MD1170, Rm. 2331/SRL, Dearborn, Michigan 48121.

19. M. W. Lloyd, Energetics, Inc., 7164 Columbia Gateway Drive, Columbia, Maryland 21046.

20. M. Mehall, Ford Motor Company, Scientific Research Laboratory, 2101 Village Road, MD-2247, Rm. 3317, Dearborn, Michigan 48124-2053.

21. N. Olds, United States Council for Automotive Research (USCAR), nolds@uscar.org

22. J. Rogers, Chemical and Environmental Sciences Laboratory, GM R\&D Center, 30500 Mound Road, Warren, Michigan 48090-9055.

23. S. A. Rogers, U.S. Department of Energy, EE-2G/Forrestal Building, 1000 Independence Avenue, S.W., Washington, D.C. 20585.

24. G. S. Smith, General Motors Advanced Technology Center, 3050 Lomita Boulevard, Torrance, California 90505.

25. E. J. Wall, U.S. Department of Energy, EE-2G/Forrestal Building, 1000 Independence Avenue, S.W., Washington, D.C. 20585.

26. B. Welchko, General Motors Advanced Technology Center, 3050 Lomita Boulevard, Torrance, California 90505.

27. P. G. Yoshida, U.S. Department of Energy, EE-2G/Forrestal Building, 1000 Independence Avenue, S.W., Washington, D.C. 20585. 